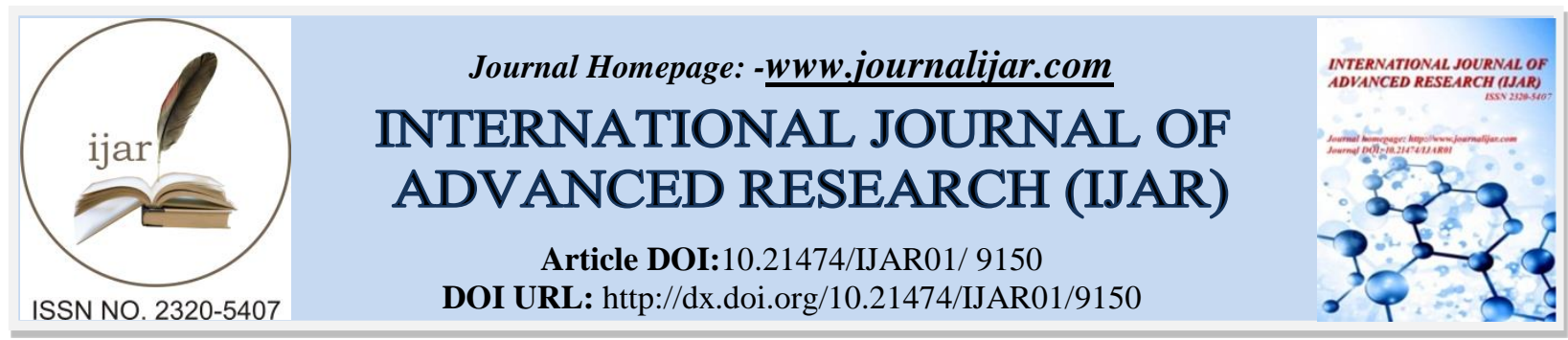

RESEARCH ARTICLE

\title{
MERCERIZED ARCHONTOPHOENIX ALEXANDRAE (KING PALM) FIBRE AND THE CONSEQUENCE OF PULLING FORCE ON ITS REINFORCEMENT IN EPOXY MATRIX.
}

Nnamdi C. Iheaturu, Bibiana C. Aharanwa, Henry C. Obasi and Uchenna L. Ezeamaku.

Department of Polymer \& Textile Engineering, Federal University of Technology, PMB 1526 Owerri, Imo State, Nigeria.

\section{Manuscript Info}

Manuscript History

Received: 24 March 2019

Final Acceptance: 26 April 2019

Published: May 2019

Key words:-

Archontophoenix Alexandrae, Epoxy resin, Natural fibre, stiffness, Young's modulus.

\section{Abstract}

Natural plant fibre was loosened from Archontophoenix Alexandrae "King palm" leaf stalk by saltwater retting and washing, then sun-dried for 2 weeks. The fibre was pulverized and treated with $4 \mathrm{M}$ sodium hydroxide $(\mathrm{NaOH})$ for 30 minutes before washing to neutralize the fibre and sun dried. The pulverized treated and untreated King palm fibre was conditioned at oven-dry weight after 70 minutes of heating in the oven at a temperature of $50{ }^{\circ} \mathrm{C}$, before introducing them into the epoxy resin for the composites casting at various weight fractions of 0.028 weight of fibre per weight of epoxy resin (w/w), $0.056 \mathrm{w} / \mathrm{w}, 0.084 \mathrm{w} / \mathrm{w}$ and 0.112 w/w. The epoxy composites were suddenly pulled $10 \mathrm{~m} / \mathrm{min}$ using the Testometric Universal Testing machine. The consequences of sudden pull on the reinforced epoxy matrix were noted. Mean values of force at break, stress at break, elongation at break, ultimate stress, and Young's modulus were obtained for epoxy composites reinforced with treated and untreated King palm staple fibre. Results show that increased weight fraction of the treated King palm fibre in epoxy resin increased the mean force at break from $150.75 \mathrm{~N}$ for the unreinforced epoxy resin to 424.07 $\mathrm{N}$ for the reinforced epoxy resin and mean Young's modulus from $404.82 \mathrm{Nm}^{-2}$ for the unreinforced epoxy to $1088.7 \mathrm{Nm}^{-2}$ and $1906 \mathrm{Nm}^{-2}$ for the treated and untreated King palm fibre reinforced epoxy composites respectively. The mean ultimate stress, mean stress at break and mean yield point at break were also higher with increased weight fraction of the reinforcement from 0.028 to 0.112 in both cases of treated and untreated King palm fibre reinforced epoxy composites. However, the mean elongation at break, reduced from $4.233 \mathrm{~mm}$ for the unreinforced epoxy to $1.5173 \mathrm{~mm}$ and $3.3267 \mathrm{~mm}$ respectively for the treated and untreated King palm fibre reinforced epoxy composites. All the composites exhibited a pre-tensioning period, while increase in the weight fraction of the King palm fibre increased brittleness of the epoxy composites. 


\section{Introduction:-}

Archontophoenix Alexandrae, otherwise called "King Palm", is of the palm family Arecaceae. It is an ornamental palm tree native to Australia. It occurs along much of the Queensland east coast of Australia. However, in Nigeria, the palm has found usefulness for beautification in estates and gardens. Alexander Palms have slightly bulbous, pale grey trunks of about $20 \mathrm{~cm}$ in diameter. The Alexander palm grows to about $15 \mathrm{~m}$ tall and is self-cleaning. They are very popular palms for frost-free conditions and are best grown in a full sun position. The crown shaft, when dry, falls off from the tree and its fibres may be extracted and used for reinforcement purposes in bricks and polymer composites. Figure 1 displays the ornamental King palm used for beautification in an estate in Nigeria.

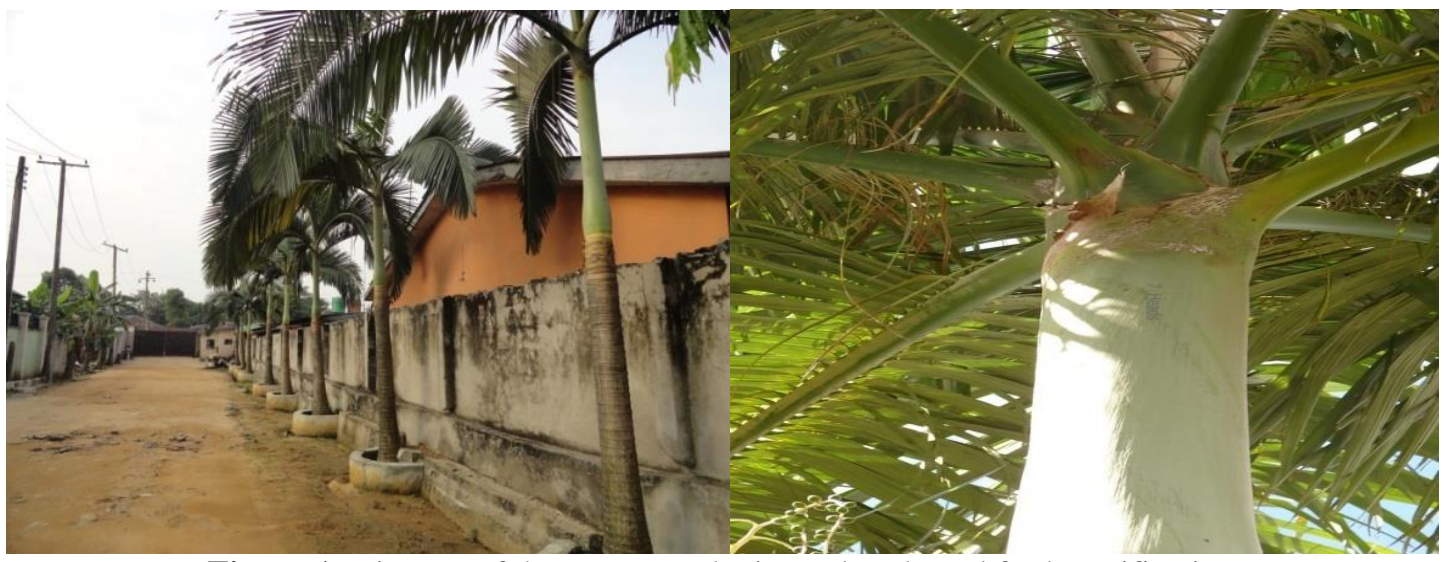

Figure 1:-Pictures of the ornamental King palm planted for beautification

\section{Literature Review}

Several researchers have written articles on natural fibres reinforced composites. In a life cycle assessment of plant and glass fibres, Joshi, Drzal, Mohanty \& Arora, (2004) identified four major areas of comparative advantage of natural plant fibre over glass fibre, to include; lower environmental impact in the production of natural plant fibres, higher utilization capacity in terms of fibre weight fraction per unit mass of resin for equivalent performance compared to glass fibres which helps to reduce waste, improvement of fuel efficiency by the use of lightweight to strength natural plant fibres, possibility of energy recovery and carbon credit at the end-of-life incineration of natural plant fibres. As a result, attention has shifted from environmentally unfriendly, energy consuming and expensive synthetic and glass fibres to more environmentally friendly, sustainable less energy consuming and cost-effective natural plant fibres, yet achieving the same desired results, even when natural plant fibres are characterized by defects such as fibre dislocations, kinks, micro-compressions in addition to their affinity for moisture (Hughes, 2012). In a bid to overcome these setbacks, the reinforcements which have been in the form of staple, ground or pulverized natural plant fibres are given various treatments before inclusion in thermoset and thermoplastic matrices. Many published works have presented various physical and chemical treatments given to the plant fibres, the effects of such treatments on the polymer composites and end use of the composites. Natural fibres of jute (Doan, Brodowsky, \& Mäder, 2012), vakka, date and bamboo (Dash, Samanta, Gautam, \& Murlidhar, 2013; Murali Mohan Rao, Mohana Rao, \& Ratna Prasad, 2010), flax (Yan, Chouw, \& Jayaraman, 2014), sisal (Ramzy, Beermann, Steuernagel, Meiners, \& Ziegmann, 2014; Rong, Zhang, Liu, Yang, \& Zeng, 2001), kenaf (Azwa \& Yousif, 2013; Fiore, Di Bella, \& Valenza, 2015; Mahjoub, Yatim, Mohd Sam, \& Raftari, 2014; Mutasher, Poh, Than, \& Law, 2011; Rassmann, Paskaramoorthy, \& Reid, 2011), hemp (Di Landro \& Janszen, 2014; Scarponi \& Messano, 2014), sugarcane bagasse (Jiménez et al., 2017), banana (Jústiz-Smith, Virgo, \& Buchanan, 2008; Sapuan, Leenie, Harimi, \& Beng, 2006), pineapple leaf fibre (Xie, Hill, Xiao, Militz, \& Mai, 2010), coconut coir (Tudu, 2009; Wei Wang \& Huang, 2009) and palm kernel coir fibres (Hill, Khalil, \& Hale, 1998; Obasi et al., 2014; Sreekala \& Thomas, 2003) have been used as reinforcement in various thermoset and thermoplastic polymers. Interestingly, most of the articles gave account of a general effect of natural fibre alkali treatment using sodium hydroxide $(\mathrm{NaOH})$ on mechanical properties (Ardhyananta, Ismail, \& Takeichi, 2007), leading to increased stiffness but decreased toughness, flexural strength and water absorption (Fisher, 1994; Lau \& Ho, 2011; W Wang, Sain, \& Cooper, 2006). In other to avert catastrophic consequences as a result of a pulling force, fibre-matrix interface bonds are enhanced by any alkali dissolution of hemicellulose, lignin, natural waxes and oils that may serve as sources of defects on the fibre-matrix interface within the composite material. 


\section{Natural plant fibres mercerization}

Mercerization refers to the use of alkali to treat fibres, with the sole aim of modifying the surface structure of the fibres. Mercerization affects cellulose fibres both chemically and physically. Chemically, mercerization exposes the hydrophilic hydroxyl groups on the cellulosic fibre surface thereby increasing the fibre substrate's affinity to dyes and other chemicals, increasing the surface area for reaction with surrounding hydrophobic polymer matrix and the interference of hydrogen bonding in the network structure in order to ionize the functional hydroxyl groups on the fibres to alkoxides thereby increasing hydrophobicity of the fibres. Cellulose structure is shown in Figure 2, while equation 1 displays the reaction chemistry of mercerized cellulose fibres using sodium hydroxide $(\mathrm{NaOH})$ solution. During mercerization, cellulose I which has parallel chain conformation shown in Figure 2, is converted to an antiparallel, amorphous cellulose II conformation.

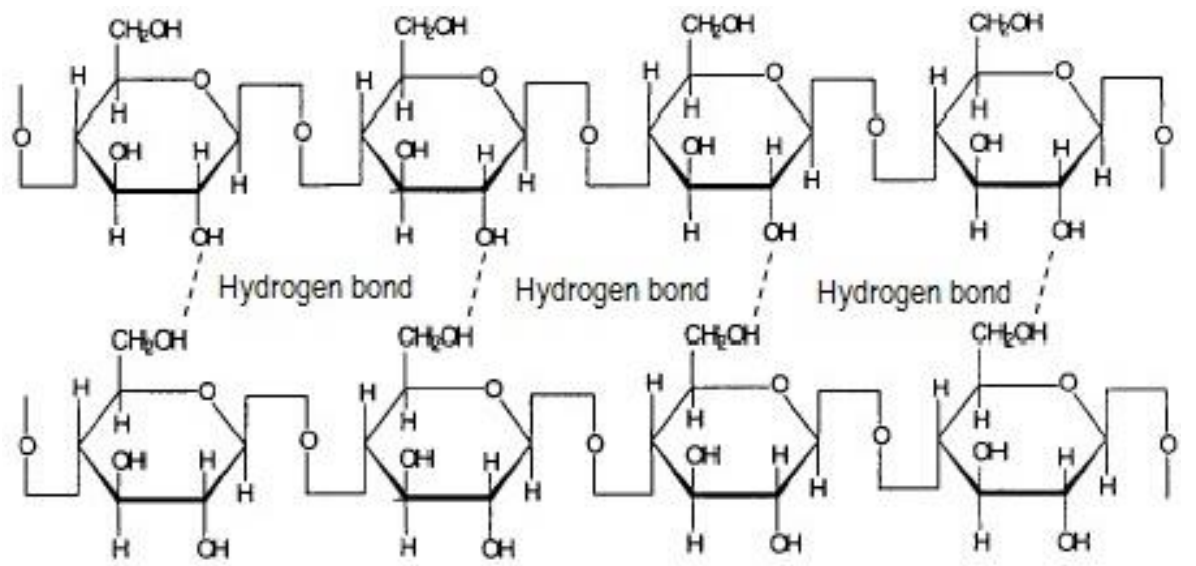

Figure 2:-Structural formula of cellulose

Fibre- $\mathrm{OH}+\mathrm{NaOH} \rightarrow$ Fibre- $\mathrm{O}^{2-}-\mathrm{Na}^{+}+\mathrm{H}_{2} \mathrm{O} \quad$ Equation (1)

Physically, mercerization affects the microstructure of the fibre by removing a substantial amount of natural lignin matrix which naturally bonds the crystalline cellulose fibres together, cleans up pectin, waxes and oils covering the micropore structure of the fibre wall. Mercerization also partially depolymerizes cellulose and hemicellulose macromolecules, exposes the short length cellulose crystallites and creates some level of disorder in the cellulose chains arrangement. The extent mercerization affects the properties of the cellulose fibres largely depends on the type of alkali used for the chemical treatment, temperature of the process, period of time the fibres remain in the alkali solution and whether or not the fibres are in tension or relaxed in their bulk state. Alkali treatment has improved the interfacial bonding and shear strength between fibre and polymer matrix (Valadez-Gonzalez, Cervantes-Uc, Olayo, \& Herrera-Franco, 1999), leading to improved mechanical properties of epoxy resin reinforced with alkali treated kenaf fibres (Mutasher et al., 2011), unsaturated polyester resin reinforced with alkali treated kenaf and hemp bast fibres (Aziz \& Ansell, 2010), epoxy resin reinforced with alkali treated banana and coconut fibres (Kongkaew, 2016) palm kernel coir fibres (Obasi et al., 2014), different polymer matrices including polypropylene (PP), poly(lactic) acid (PLA), epoxy and phenolic resins reinforced with treated flax fibres (Zhu, Zhu, Njuguna, \& Abhyankar, 2013). In the meantime, a comparative evaluation of the use of treated and untreated King palm fibre either as staple, ground or pulverized fibres in any thermoset or thermoplastic material has not been reported. This work, therefore, considers the consequence of a sudden pulling force on epoxy matrix reinforced with Archontophoenix Alexandrae (King palm fibre - KPF) treated with sodium hydroxide $(\mathrm{NaOH})$. This was done in order to check the response of the epoxy reinforced composites to sudden pulling shock.

\section{Materials and Methods:-}

\section{King palm fibre extraction}

Dry King palm fibre (KPF) was cut-off manually from the leaf stalk. The fibre was loosened from the palm leaf stalk by salt water retting for 7 days, washing, de-fibring and washing again, then sun-dried for 2 weeks. This made the cut leaves soft and loose, releasing the sandwiched fibre from the matt. The loosened, sun-dried fibre was then pulverized. 


\section{Alkali treatment with $\mathrm{NaOH}$}

$4 \mathrm{~g}, 8 \mathrm{~g}, 12 \mathrm{~g}, 16 \mathrm{~g}$ of sodium hydroxide $(\mathrm{NaOH})$ pellets respectively were dissolved in 4 different beakers containing $100 \mathrm{ml}$ of $\mathrm{NaOH}$ to prepare $1 \mathrm{M}, 2 \mathrm{M}, 3 \mathrm{M}$, and $4 \mathrm{M}$ solution of $\mathrm{NaOH}$. $15 \mathrm{~g}$ of the dried pulverized King Palm fibre was soaked in the molar solutions of the $\mathrm{NaOH}$ for 30 minutes. The mixture was mechanically stirred for another 30 minutes. The fibre was then filtered and washed repeatedly with distilled water to neutralize the $\mathrm{NaOH}$ solution. Dilute tetraoxosulphate $\mathrm{VI}\left(\mathrm{H}_{2} \mathrm{SO}_{4}\right)$ acid was used to titrate the $\mathrm{NaOH}$ solution from washing with a view to finding the end point indicating neutrality of the fibre before final filtration of the fibre and sun drying for 7 days. Methyl orange was used as indicator. Figure 3 shows the pulverized, $\mathrm{NaOH}$ treated, washed and dried King palm fibre.

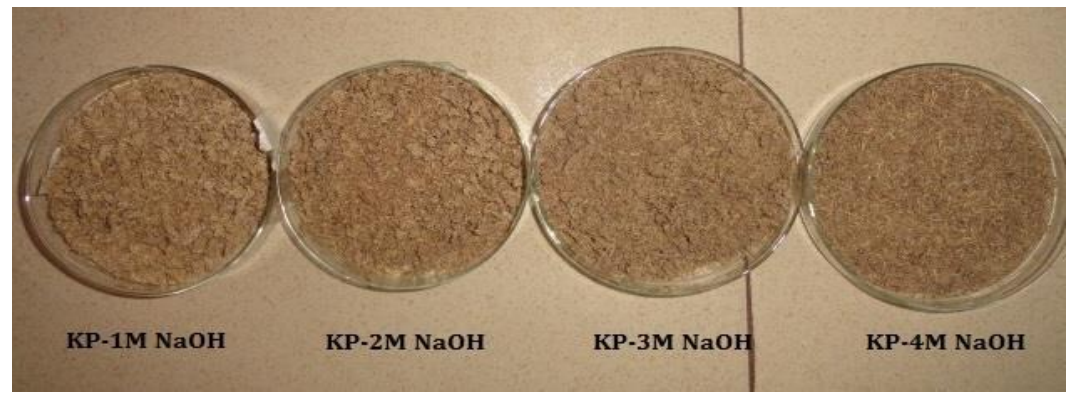

Figure 3:-KPF treated with various concentrations of $\mathrm{NaOH}$

\section{FTIR Characterization of King Palm Fibre}

FT-IR spectroscopic analysis of the untreated and treated king palm fibre (KPF) was carried out using a Perkin Elmer Spectrometer 2000 IR. Potassium bromide (KBr) pellets were used. The scanned range was $400-4000 \mathrm{~cm}^{-1}$.

\section{Moisture content}

Moisture content determination was carried out on the mercerized King palm fibre using the oven-dry-weight method with laboratory oven model: TT-9023A and high precision weighing balance model: FA 22043. Heating was done at a mild temperature of $50{ }^{\circ} \mathrm{C}$ and oven dried KPF was weighed at 10 minutes interval.

\section{Resin materials used}

A two-part resin system comprising epoxy and polyamide hardener with pot-life of 120 minutes, was obtained from Raychem Harnessing GmbH \& Co. KG, Germany. No special preparation was carried out on the epoxy resin, rather safety precautions and formulation ratio of matrix and hardener was adhered to strictly in using both resins. Mixing was done by measuring two parts by weight of the epoxy resin, $72 \mathrm{~g}$, and three parts by weight, $108 \mathrm{~g}$, of the polyamide hardener.

\section{Composite fabrication}

The formulations used in casting dog-bone shaped composites shown in Figure 4, using the silicone mould are shown in Table 1. Various weight fractions of weight of fibre per weight of epoxy resin (w/w) thus $0.028 \mathrm{w} / \mathrm{w}, 0.056 \mathrm{w} / \mathrm{w}$, $0.084 \mathrm{w} / \mathrm{w}$ and $0.112 \mathrm{w} / \mathrm{w}$, of the $4 \mathrm{M} \mathrm{NaOH}$ solution treated and untreated pulverized King palm natural fibre was mixed with the epoxy resin and hardener using a high-speed mixer before pouring it into the silicon mould. The cast samples were allowed to cure in the open air at $27^{\circ} \mathrm{C}$ for 24 hours.

Table 1:-Dumb-bell epoxy composites formulation

\begin{tabular}{|l|l|}
\hline Epoxy / hardener ratio (grams) & Weight fraction $(\mathrm{w} / \mathrm{w})$ \\
\hline 72 Epoxy: 108 Polyamide hardener & 0 \\
\hline 72 Epoxy: 108 Polyamide hardener & 0.028 \\
\hline 72 Epoxy: 108 Polyamide hardener & 0.056 \\
\hline 72 Epoxy: 108 Polyamide hardener & 0.084 \\
\hline 72 Epoxy: 108 Polyamide hardener & 0.112 \\
\hline
\end{tabular}




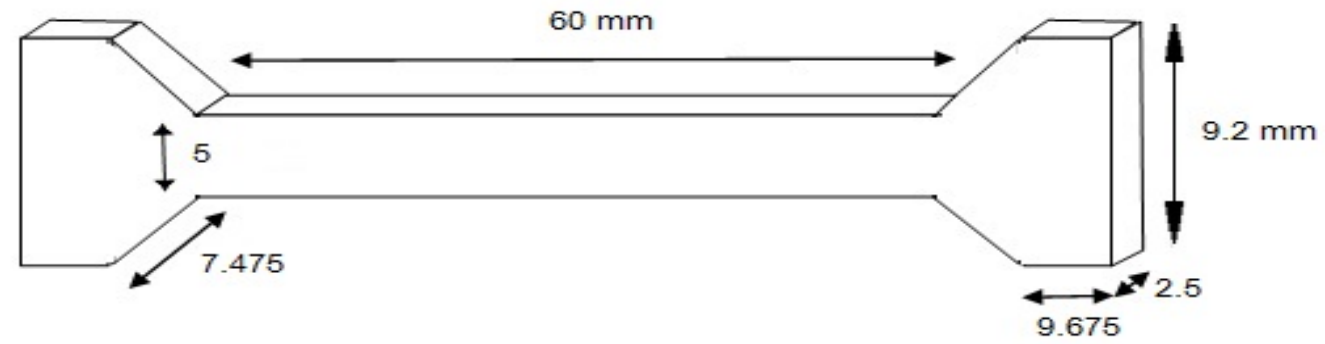

Figure 4:-Dimensions of dog-bone epoxy composite sample. All dimensions in millimeters (mm)

\section{Composites pulling test}

Pull testing of the composite samples was done according to ASTM D 638 procedure for testing of polymer composites, using the Testometric Universal Testing (TUT) machine. The machine is composed of two jaw grips, one movable and one stationary jaw set $60 \mathrm{~mm}$ apart which corresponded to the gauge length of the composite samples. The composites were pulled at a crosshead speed of $10 \mathrm{~m} / \mathrm{min}$ until breaking point.

\section{Results and Discussions:- Results of FTIR}

FTIR spectra of the untreated and treated KPF at various concentrations of $\mathrm{NaOH}$ is shown in Figure 5. The five spectra have been plotted on one graph to compare the extent of mercerization on the cellulose fibre.

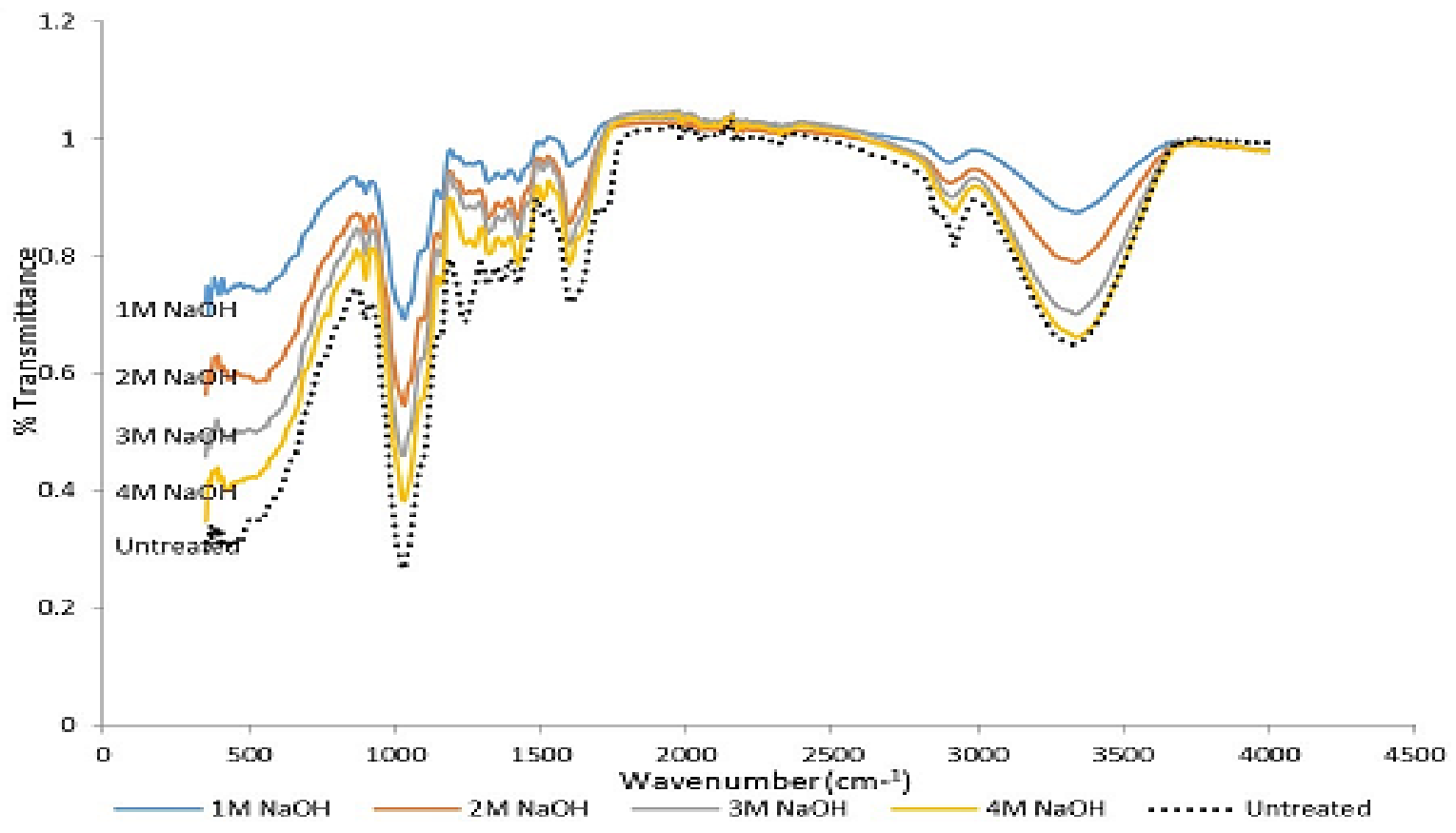

Figure 5:-FTIR of untreated and $\mathrm{NaOH}$ treated $\mathrm{KPF}$ at various concentrations

Figure 5 displays the FTIR spectrum of untreated and treated with $\mathrm{NaOH}$. The peak at $1031 \mathrm{~cm}^{-1}$ is a major peak for cellulosic fibres indicating in and out-of-plane vibrations of $-\mathrm{CH}_{2} \mathrm{OH}$ functional group, a characteristic of every cellulosic fibre as shown in Figure 2. However, treatment of the King palm fibre with varied concentrations of $\mathrm{NaOH}$ from $1 \mathrm{M}$ to $4 \mathrm{M}$, caused an increased intensity of this peak and others. It can be inferred that a substantial portion of uranic acid which is a major substituent of hemicellulose xylem may have been washed off by the $\mathrm{NaOH}$ solution which invariably weakens the fibre at higher $\mathrm{NaOH}$ concentrations. Furthermore, the doublet peaks at $1200 \mathrm{~cm}^{-1}$ and $1231 \mathrm{~cm}^{-1}$ are indicative of alkali treatment. The peaks at $890 \mathrm{~cm}^{-1}$ and $1452 \mathrm{~cm}^{-1}$ indicates the asymmetric stretching of aryl group of phenyl $\left(-\mathrm{C}_{6} \mathrm{H}_{5}\right)$ in lignin and methylene $\left(-\mathrm{CH}_{2}\right)$ bending vibrations respectively, while the shoulder peak at $1726 \mathrm{~cm}^{-1}$ corresponds to carbonyl $(\mathrm{C}=\mathrm{O})$ stretching of the ester linkage of the lignin and acetyl $\left(-\mathrm{COCH}_{3}\right)$ group of hemicellulose. The shoulder at $2856 \mathrm{~cm}^{-1}$ and the peak at $2922 \mathrm{~cm}^{-1}$ represent C-H symmetric bending 
vibrations. The intense but broad peak stretching from $3010 \mathrm{~cm}^{-1}$ to $3700 \mathrm{~cm}^{-1}$ majorly attributed to asymmetric stretching vibrations of hydrogen-bonded $\mathrm{OH}$ which intensities also increased with increase in $\mathrm{NaOH}$ concentration. Chemically, the reaction scheme for the treatment with sodium hydroxide is given in Equation 2.

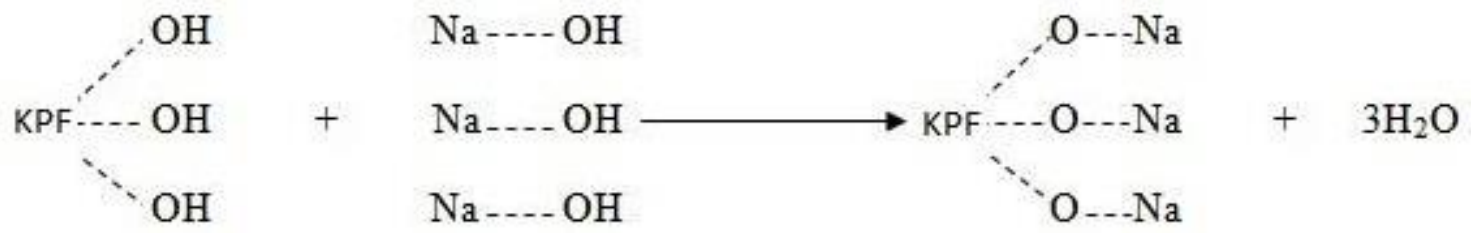

Equation 2:- Reaction scheme for the treatment of KPF with sodium hydroxide

\section{Moisture content analysis of treated KPF}

The moisture content of the $4 \mathrm{M} \mathrm{NaOH}$ solution treated King palm fibre was determined and the values obtained from the oven-dry weight experiment was plotted in Figure 6.

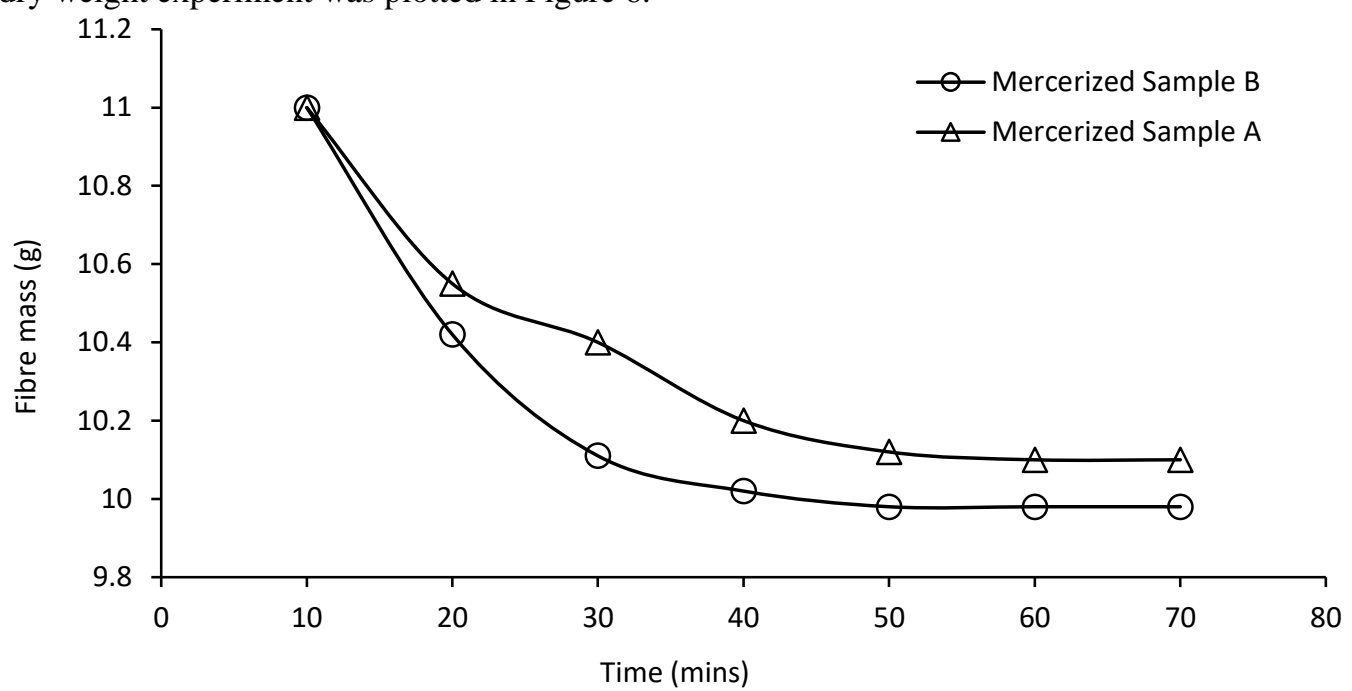

Figure 6:-Moisture content of mercerized KPF

The $4 \mathrm{M} \mathrm{NaOH}$ solution treated King palm fibre was conditioned at oven-dry weight after 70 minutes of heating in the oven at a mild temperature of $50{ }^{\circ} \mathrm{C}$, before introducing them into the epoxy resin for the composites casting.

\section{Results of Pulling Test}

The results of pulling test of the King Palm natural fibre reinforced epoxy composites are presented in the stress-strain plots of Figures 7 to 15. All the stress-strain graphs show a pre-tensioning stage of the composites from points $\mathrm{O}$ to $\mathrm{A}$ as indicated on the graphs. After point A, an increase in stress corresponded with an increase in strain till breaking point.

\section{Tensile properties of unreinforced epoxy composites}

Two samples were tested for the unreinforced epoxy composites as shown in Figure 7. From the graph, the mean values for the force at break, stress at break, elongation at break, ultimate stress, and Young's modulus were estimated. 


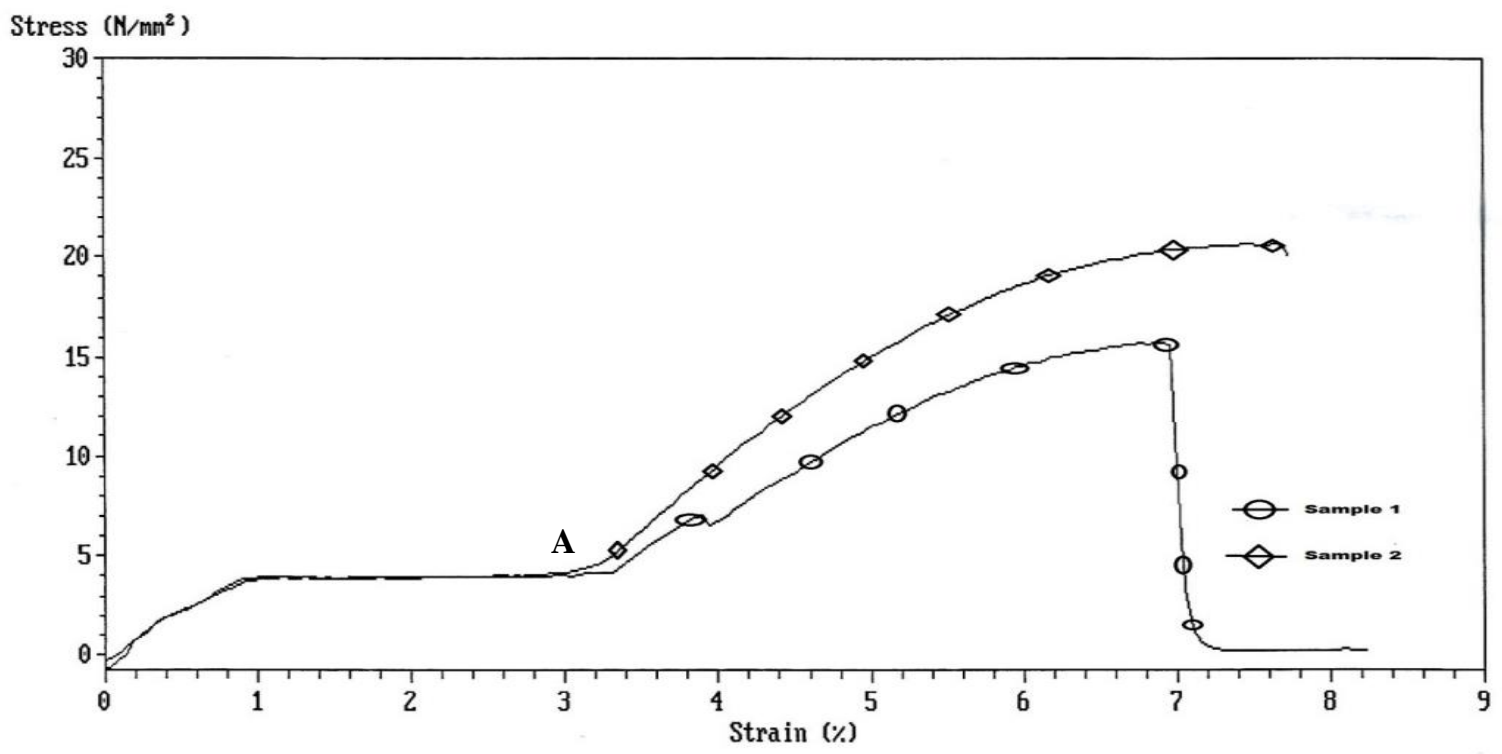

Figure 7:-Stress-Strain graph of unreinforced epoxy matrix

The epoxy materials exhibited a pre-tensioning period with low tensile strength and high strain. From point A, the mean stress increased from about $4.9 \mathrm{Nm}^{-2}$ to about $18.12 \mathrm{Nm}^{-2}$ yield stress. For the unreinforced epoxy material, the mean elongation at break was $4.233 \mathrm{~mm}$, mean ultimate stress was $18.12 \mathrm{Nm}^{-2}$, mean yield stress at break was 12.263 $\mathrm{Nm}^{-2}$ and Young's modulus was $404.82 \mathrm{Nm}^{-2}$.

Tensile properties of epoxy composites reinforced with untreated King palm fibre Again, two samples were tested for the epoxy composites reinforced with 0.028 weight fraction of untreated King palm natural fibre as shown in the stress-strain graph of Figure 8.

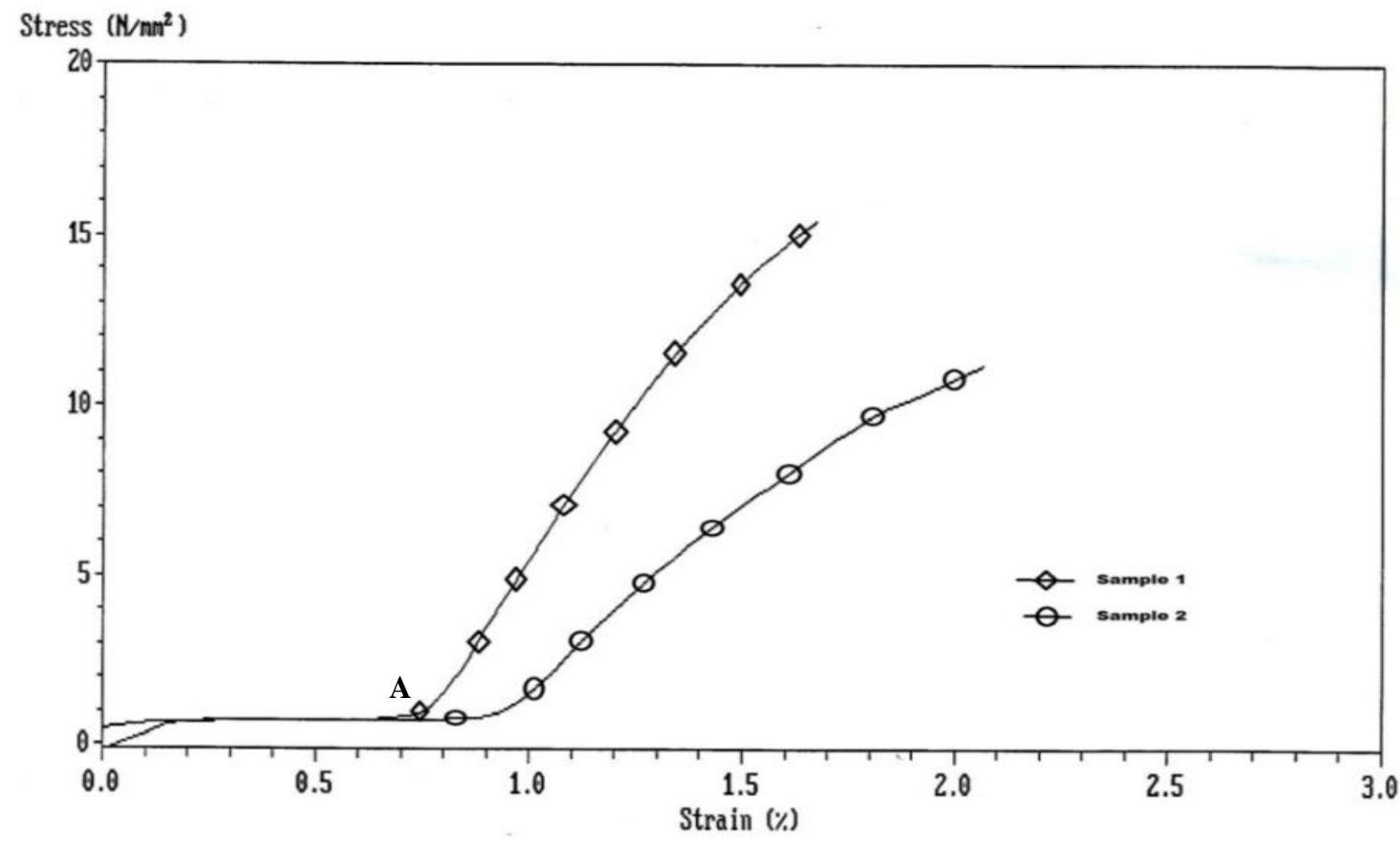

Figure 8:-Stress-Strain graph of epoxy composites reinforced with 0.028 weight fraction of untreated King palm fibre 
From Figure 8, the mean values for the force at break, stress at break, elongation at break, ultimate stress, and Young's modulus were estimated from the two plots. The epoxy materials exhibited a pre-tensioning period at very low stress. From point $\mathrm{A}$, the mean stress increased from about $0.07 \mathrm{Nm}^{-2}$ to about $15.05 \mathrm{Nm}^{-2}$. While the mean elongation at break was $1.7785 \mathrm{~mm}$, mean ultimate stress was $13.297 \mathrm{Nm}^{-2}$, mean yield stress at break was $6.061 \mathrm{Nm}^{-2}$ and Young's modulus was $1592 \mathrm{Nm}^{-2}$.

Three samples were tested for the epoxy composites reinforced with 0.056 weight fraction of untreated King palm natural fibre as shown in Figure 9 stress-strain graph.

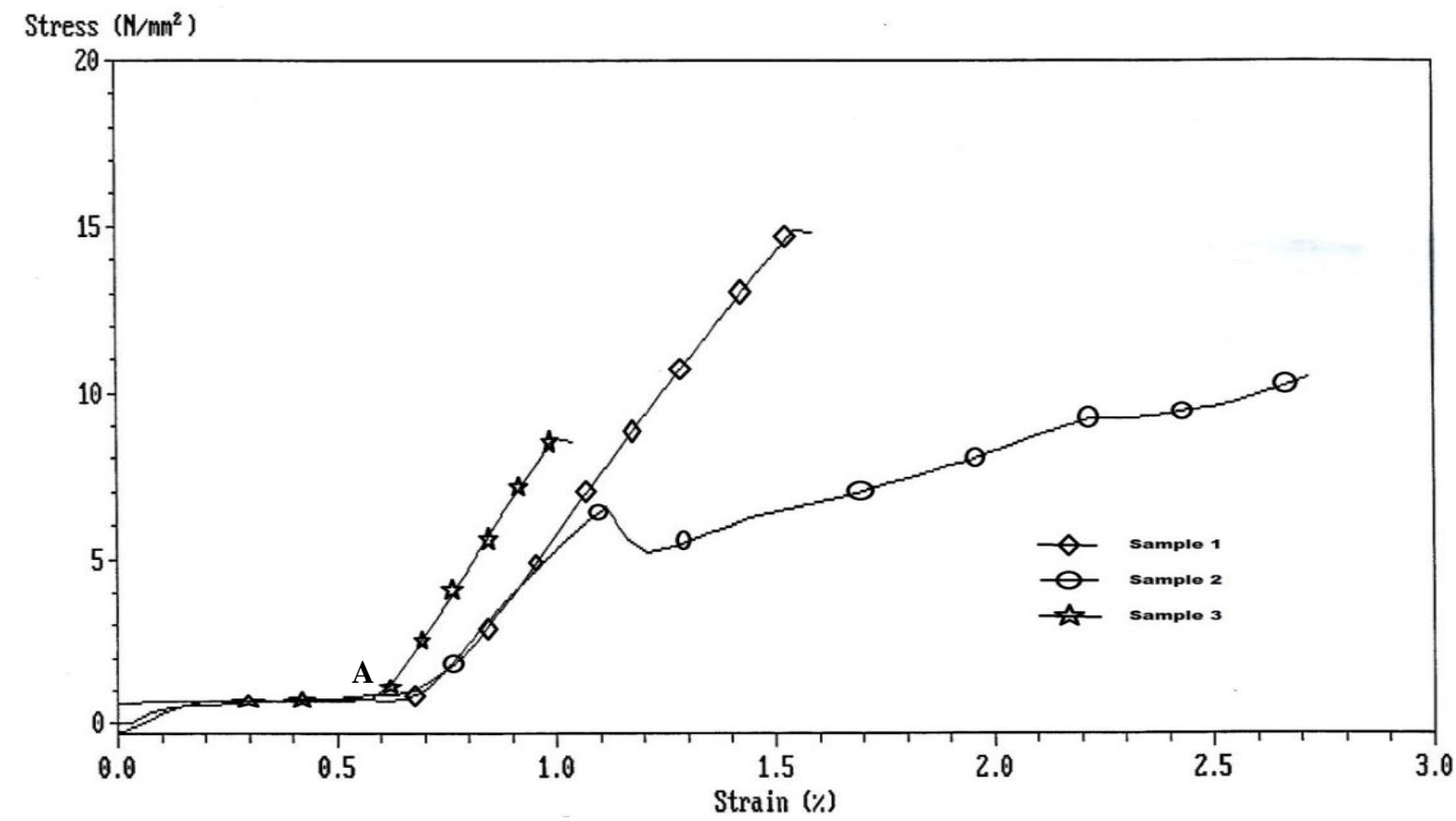

Figure 9:-Stress-Strain graph of epoxy composites reinforced with 0.056 weight fraction of untreated King palm fibre

From Figure 9, the mean values for the force at break, stress at break, elongation at break, ultimate stress, and Young's modulus were estimated from the two plots. The epoxy materials exhibited a pre-tensioning period with low tensile strength and high strain. However, from point A, the mean stress increased from about $4.9 \mathrm{~N} / \mathrm{m}^{2}$ to about $10.55 \mathrm{Nm}^{-}$ ${ }^{2}$. While the mean elongation at break was $1.6947 \mathrm{~mm}$, mean ultimate stress was $11.302 \mathrm{Nm}^{-2}$, mean yield stress at break was $9.988 \mathrm{Nm}^{-2}$ and Young's modulus was $1750 \mathrm{Nm}^{-2}$. The mean force at break was $399.37 \mathrm{~N}$.

Again, two samples were tested for the epoxy composites reinforced with 0.084 weight fraction of untreated King palm natural fibre as shown in the stress-strain graph in Figure 10. 


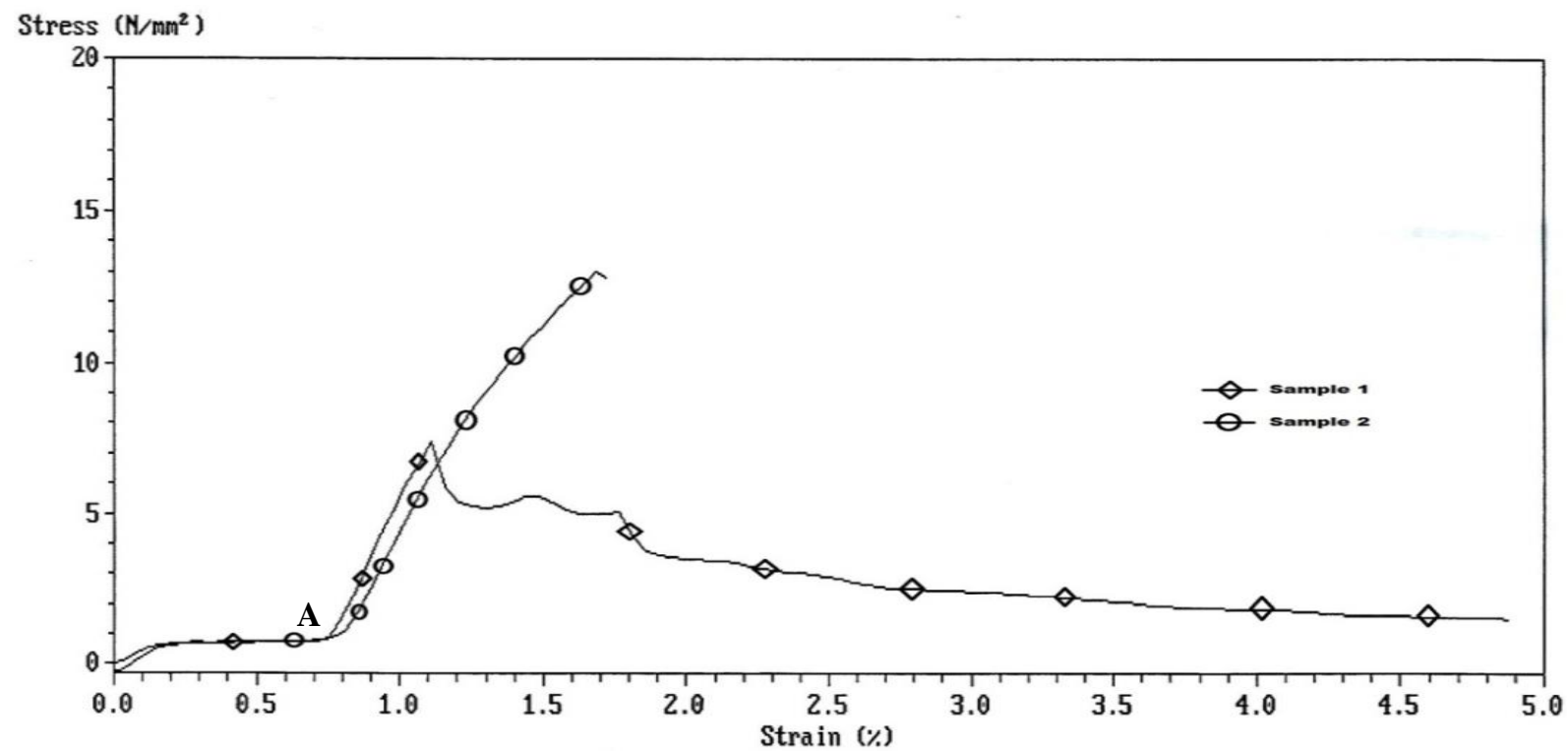

Figure 10:-Stress-Strain graph of epoxy composites reinforced with 0.084 weight fraction of untreated King palm fibre

From Figure 10, the mean values for the force at break, stress at break, elongation at break, ultimate stress, and Young's modulus were estimated from the two plots. The epoxy materials exhibited a pre-tensioning period. But from point A, the mean stress increased from about $4.9 \mathrm{Nm}^{-2}$ to about $10.05 \mathrm{Nm}^{-2}$. While, the mean elongation at break was 3.1355 $\mathrm{mm}$, mean ultimate stress was $10.16 \mathrm{~N} / \mathrm{m}^{2}$, mean yield stress was $10.161 \mathrm{Nm}^{-2}$ and Young's modulus was $1870.5 \mathrm{Nm}^{-}$ 2. At a mean force of $422.3 \mathrm{~N}$, the material broke into two pieces.

Again, two samples were tested for the epoxy composites reinforced with 0.084 weight fraction of untreated King palm natural fibre as shown in the stress-strain graph in Figure 11.

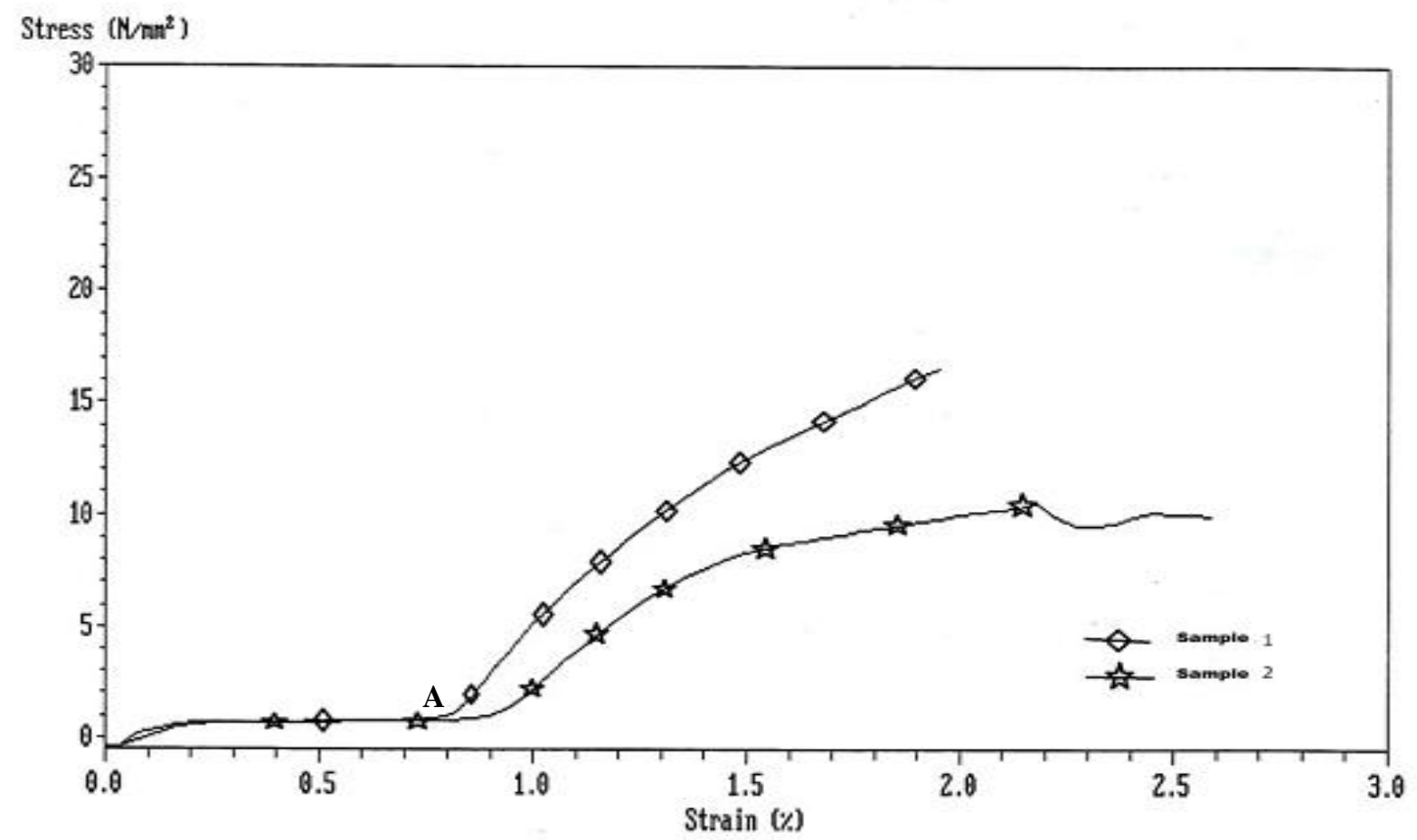

Figure 11:-Stress-Strain graph of epoxy composites reinforced with 0.112 weight fraction of untreated King palm fibre 
From Figure 11, the mean values for the force at break, stress at break, elongation at break, ultimate stress, and Young's modulus were estimated from the two plots. The epoxy materials exhibited a pre-tensioning period with low tensile strength and high strain. But from the point, A, the mean stress increased from about $0.05 \mathrm{Nm}^{-2}$ to about $10.25 \mathrm{Nm}^{-2}$. While, the mean elongation at break was $1.5173 \mathrm{~mm}$, mean ultimate stress was $15.721 \mathrm{Nm}^{-2}$, mean yield stress was 15.302 $\mathrm{Nm}^{-2}$ and Young's modulus was $1906.9 \mathrm{Nm}^{-2}$. At the breaking point, the mean force at break was $424.07 \mathrm{~N}$.

\section{Tensile properties of epoxy composites reinforced with $\mathrm{NaOH}$ treated King palm natural staple fibre}

Figure 12 is the stress-strain graph for the two epoxy composites reinforced with 0.028 weight fraction of $\mathrm{NaOH}$ treated King palm fibre.

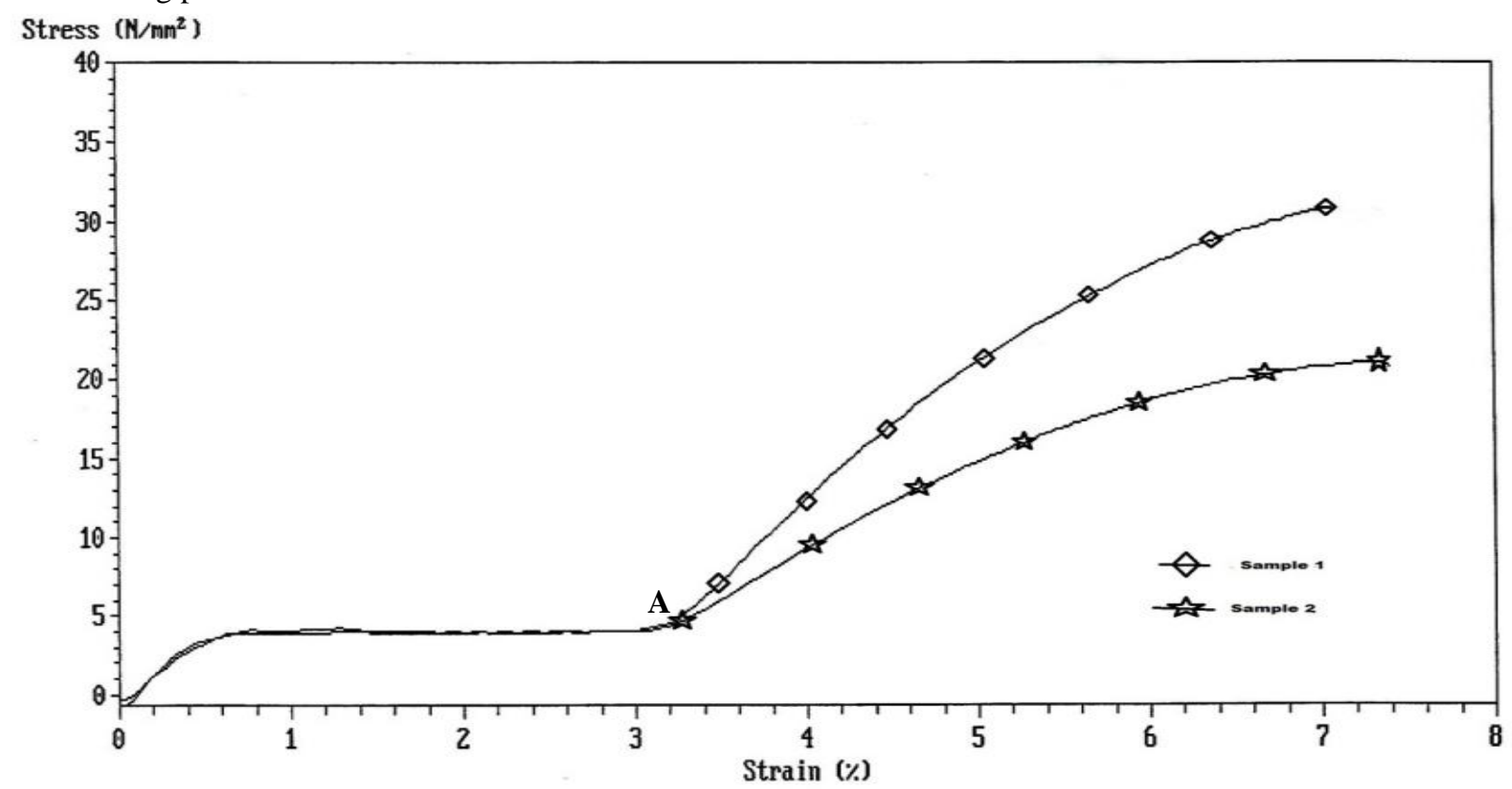

Figure 12:-Stress-Strain graph of epoxy composites reinforced with 0.028 volume fraction of $\mathrm{NaOH}$ treated King palm fibre

Figure 12 displays the effect of 0.028 weight fraction of $\mathrm{NaOH}$ treated King palm staple fibre reinforcement on the epoxy matrix. From the graph, there was a significant increase in the mean stress from $3.9 \mathrm{Nm}^{-2}$ to mean stress at break and ultimate stress at break of about $25.703 \mathrm{Nm}^{-2}$ and $25.857 \mathrm{Nm}^{-2}$ respectively. The force at break was 388.55 $\mathrm{N}$, mean elongation at break was $3.8345 \mathrm{~mm}$, mean ultimate stress was $25.875 \mathrm{Nm}^{-2}$, and mean yield stress was 25.875 $\mathrm{Nm}^{-2}$ while the mean Young's modulus was $843.5 \mathrm{Nm}^{-2}$. The mean force at break was $775.2 \mathrm{~N}$.

Figure 13 is the stress-strain graph of three dog-bone shaped epoxy composite samples of the same formulation and reinforced with 0.056 weight fraction of $\mathrm{NaOH}$ treated King palm natural fibre. 


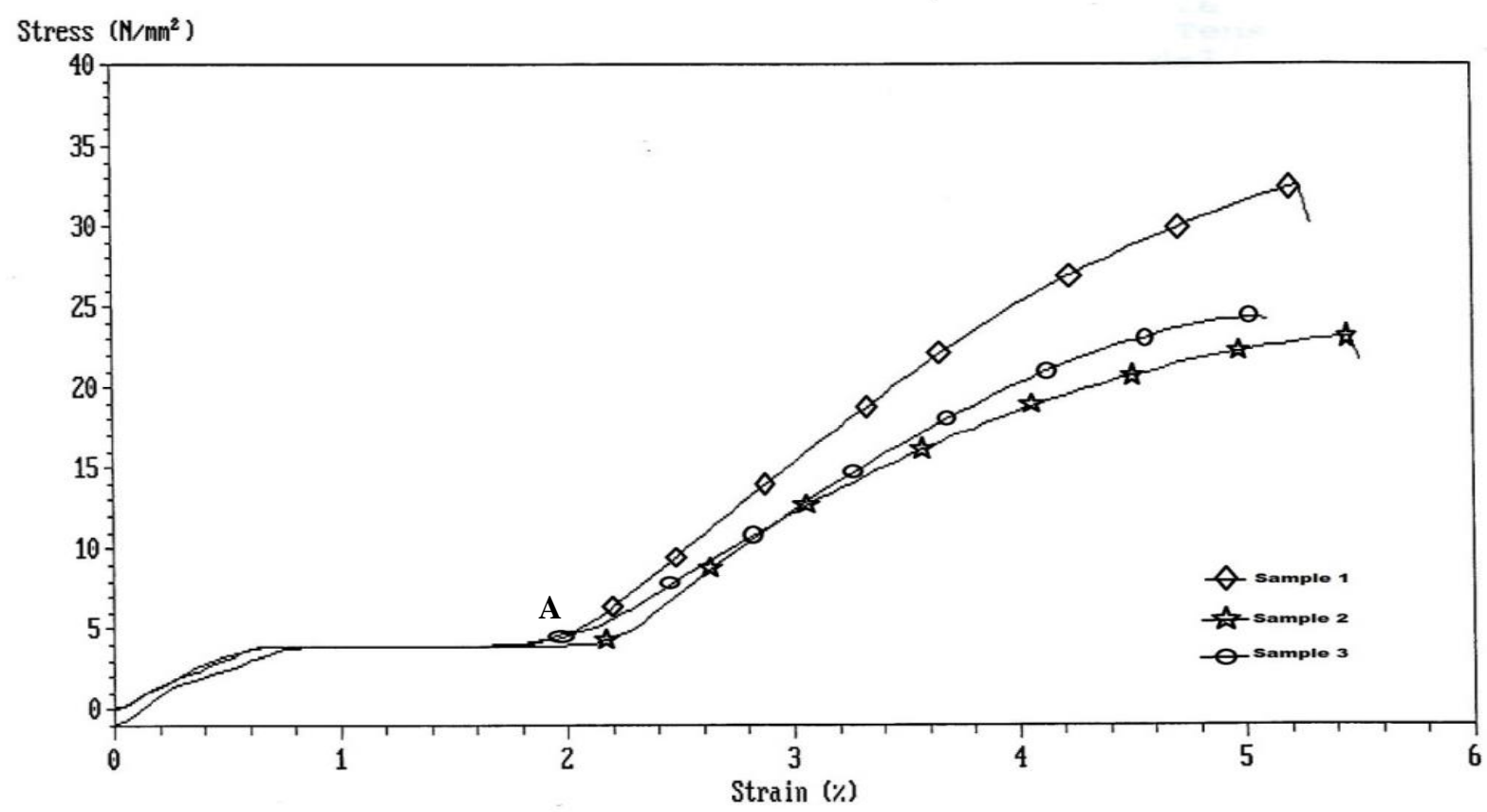

Figure 13:-Stress-Strain graph of epoxy composites reinforced with 0.056 volume fraction of $\mathrm{NaOH}$ treated King palm fibre

Figure 13 displays a progressive increase in the tensile strength of the 3 samples. The force at break was $656.27 \mathrm{~N}$, mean elongation at break was $2.7747 \mathrm{~mm}$, mean ultimate stress was $26.624 \mathrm{Nm}^{-2}$, mean stress at break was 25.193 $\mathrm{Nm}^{-2}$, mean yield stress was $26.624 \mathrm{Nm}^{-2}$, mean Young's modulus was $986.5 \mathrm{Nm}^{-2}$. The mean Young's modulus increased by $35.32 \%$ giving stiffer composites compared to the unreinforced epoxy, that reinforced with 0.028 weight fraction of $\mathrm{NaOH}$ treated King palm and that reinforced 0.056 weight fraction of untreated King palm fibre. This obviously was the reason for $164.9 \%$ increase in the mean force value to break the composites.

Figure 14 is the stress-strain curve for three dog-bone shaped epoxy composite samples reinforced with 0.084 weight fraction of $\mathrm{NaOH}$ treated staple fibre.

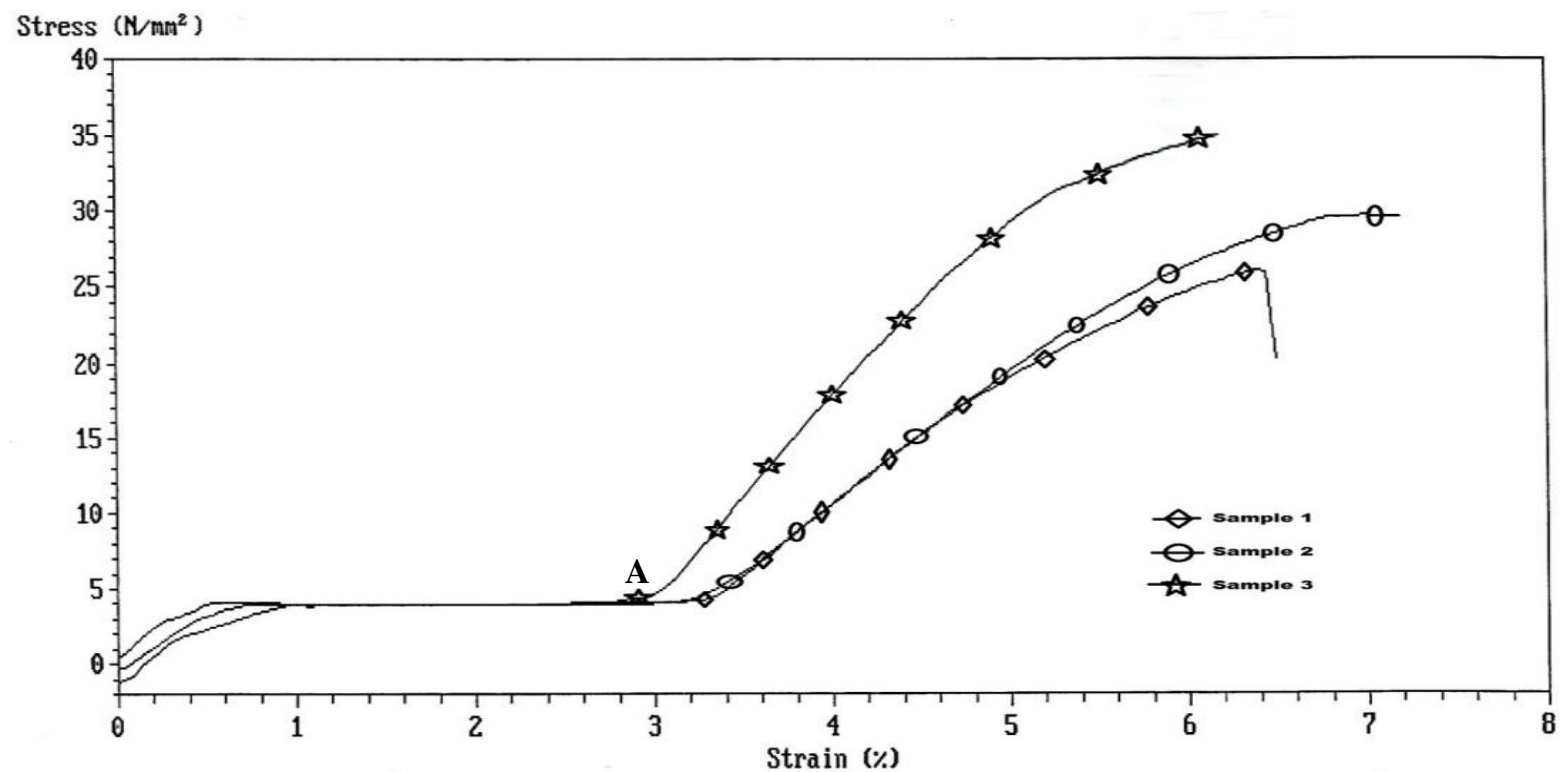

Figure 14:-Stress-Strain graph of epoxy composites reinforced with 0.084 volume fraction of $\mathrm{NaOH}$ treated King palm fibre 
Figure 14 also reveals a much high tensile strength required for the King palm staple fibre reinforced epoxy composites to fail. Force at break was $414.85 \mathrm{~N}$, mean elongation at break was $3.4527 \mathrm{~mm}$, mean ultimate stress at break was 30.2 $\mathrm{Nm}^{-2}$, mean stress at break was $28.153 \mathrm{Nm}^{-2}$, mean yield stress at break was $27.810 \mathrm{Nm}^{-2}$ and Young's modulus was 1076.7 $\mathrm{Nm}^{-2}$. Reason for the tensile strength increase may be because of the increase in matrix-reinforcement interaction as a result of a higher surface volume of the $\mathrm{NaOH}$ treated King palm fibre interacting with the epoxy matrix. Furthermore, the elongation at break may have increased due to the presence of microvoids and defect zones arising from improper wetting of the $\mathrm{NaOH}$ treated King palm fibre by the epoxy matrix. Impurities in the composite sample may also lead to weak spots at the fibre-matrix interface.

Figure 15 is the stress-strain graph for 3 dog-bone shaped epoxy composites reinforced with 0.112 weight fraction of $\mathrm{NaOH}$ treated King palm fibre.

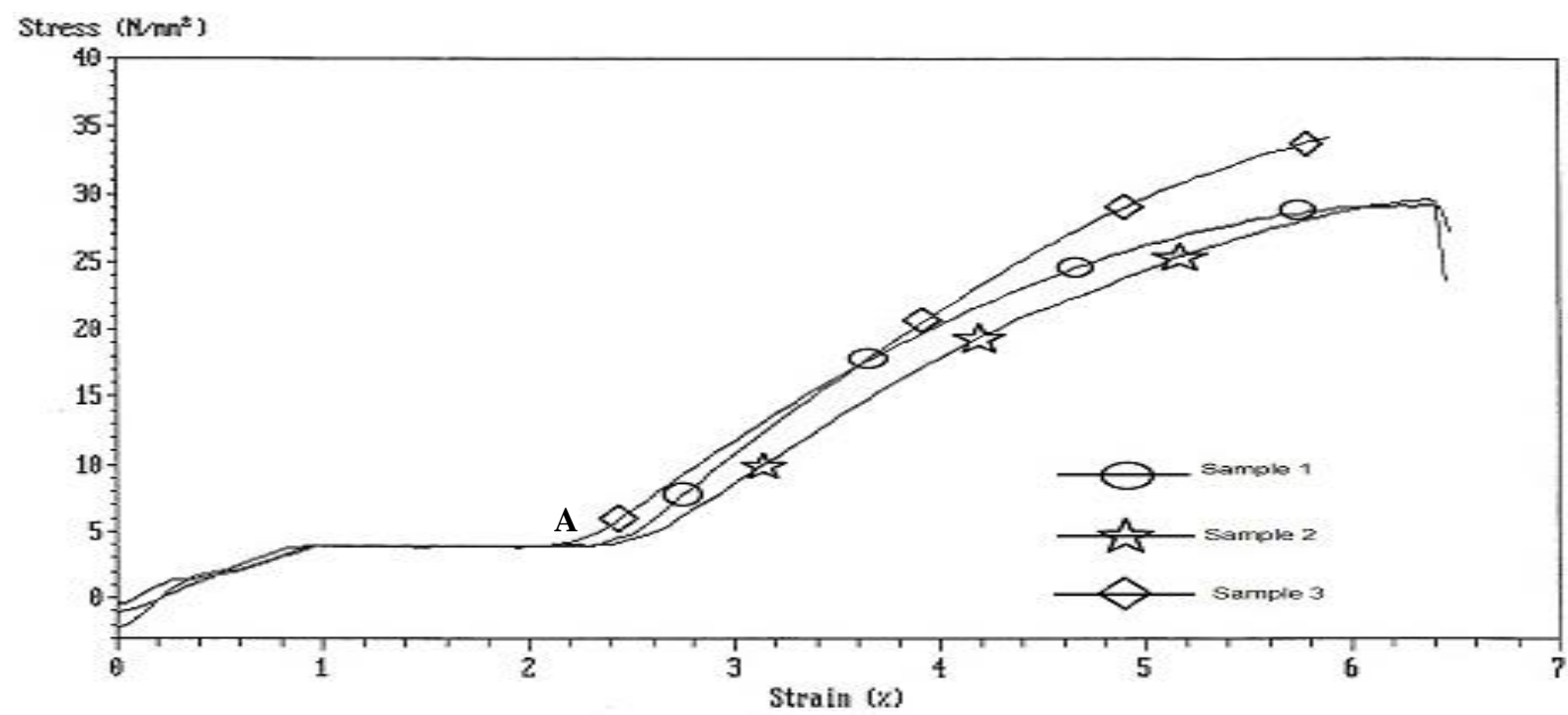

Figure 15:-Stress-Strain graph of $0.112 \mathrm{~g}$ of $\mathrm{NaOH}$ treated King Palm fibre reinforced epoxy composites

Figure 15 displays a stiffer material compared to the composites reinforced with 0.084 weight fraction of $\mathrm{NaOH}$ treated King palm fibre and those reinforced with 0.112 weight fraction of untreated King palm fibre, thus requiring the highest mean force value of $866.7 \mathrm{~N}$ to break the samples. The mean elongation at break was $3.3267 \mathrm{~mm}$, mean ultimate stress was $30.953 \mathrm{Nm}^{-2}$, mean stress at break was $28.2827 \mathrm{Nm}^{-2}$, mean yield stress was $29.29 \mathrm{Nm}^{-2}$ and mean Young's modulus was $1048.2 \mathrm{Nm}^{-2}$. The mean elongation at break decreased slightly from $3.4527 \mathrm{~mm}$ to $3.3267 \mathrm{~mm}$ representing $3.65 \%$ decrease which may be as a result of the presence of microvoids defect zones in the epoxy composites. Microvoids very close to the $\mathrm{NaOH}$ treated fibre may cause a reduction of the bond strength between the epoxy matrix and the $\mathrm{NaOH}$ treated King palm fibre interface leading to a slight reduction in the mean value for the elongation at break, the mean yield stress and the stiffness.

Effect of of untreated and $\mathrm{NaOH}$ treated fibre weight fractions on tensile properties of the epoxy composites Table 2 presents values obtained from the tensile test carried out using the testometric universal testing machine on the epoxy composites reinforced with untreated King palm fibre, while Table 3 presents results obtained from the tensile test carried out on the epoxy composites reinforced with $\mathrm{NaOH}$ treated King palm fibre.

Table 2:- Mechanical properties of epoxy composites reinforced with untreated King palm fibre

\begin{tabular}{|l|l|l|l|l|l|l|}
\hline $\begin{array}{c}\text { Fibre } \\
\text { weight } \\
\text { fraction }\end{array}$ & $\begin{array}{c}\text { Mean } \\
\text { Force at } \\
\text { break (N) }\end{array}$ & $\begin{array}{c}\text { Mean } \\
\text { Elongation at } \\
\text { break (mm) }\end{array}$ & $\begin{array}{c}\text { Mean Ultimate } \\
\text { stress }\left(\mathrm{Nm}^{-2}\right)\end{array}$ & $\begin{array}{c}\text { Mean Stress } \\
\text { at break } \\
\left(\mathrm{Nm}^{-2}\right)\end{array}$ & $\begin{array}{c}\text { Mean Yield } \\
\text { stress at break } \\
\left(\mathrm{Nm}^{-2}\right)\end{array}$ & $\begin{array}{c}\text { Mean Young's } \\
\text { Modulus }\left(\mathrm{Nm}^{-}\right. \\
2)\end{array}$ \\
\hline 0 & 150.75 & 4.2330 & 18.120 & 10.050 & 12.263 & 404.82 \\
\hline 0.028 & 388.55 & 1.7785 & 10.161 & 13.297 & 6.061 & 843.5 \\
\hline 0.056 & 399.37 & 1.6947 & 11.302 & 12.257 & 9.988 & 986.5 \\
\hline 0.084 & 422.3 & 1.2355 & 13.297 & 13.516 & 10.161 & 1076.7 \\
\hline 0.112 & 424.07 & 1.5173 & 15.721 & 14.867 & 15.302 & 1088.2 \\
\hline
\end{tabular}


Table 3:-Mechanical properties of epoxy composites reinforced with $\mathrm{NaOH}$ treated King palm fibre

\begin{tabular}{|l|l|l|l|l|l|l|}
\hline $\begin{array}{c}\text { Fibre } \\
\text { weight } \\
\text { fraction }\end{array}$ & $\begin{array}{c}\text { Mean } \\
\text { Force at } \\
\text { break (N) }\end{array}$ & $\begin{array}{c}\text { Mean } \\
\text { Elongation at } \\
\text { break }(\mathrm{mm})\end{array}$ & $\begin{array}{c}\text { Mean Ultimate } \\
\text { stress }\left(\mathrm{Nm}^{-2}\right)\end{array}$ & $\begin{array}{c}\text { Mean Stress } \\
\text { at break } \\
\left(\mathrm{Nm}^{-2}\right)\end{array}$ & $\begin{array}{c}\text { Mean Yield } \\
\text { stress at break } \\
\left(\mathrm{Nm}^{-2}\right)\end{array}$ & $\begin{array}{c}\text { Mean Young's } \\
\text { Modulus }\left(\mathrm{Nm}^{-}\right. \\
2\end{array}$ \\
\hline 0 & 150.75 & 4.2330 & 18.120 & 10.050 & 12.263 & 404.82 \\
\hline 0.028 & 775.2 & 3.8345 & 25.857 & 25.703 & 25.857 & 1592 \\
\hline 0.056 & 656.27 & 2.7747 & 26.624 & 25.193 & 26.624 & 1750.7 \\
\hline 0.084 & 414.85 & 3.4527 & 30.200 & 28.153 & 27.810 & 1870.5 \\
\hline 0.112 & 866.7 & 3.3267 & 30.953 & 28.2827 & 29.290 & 1906.9 \\
\hline
\end{tabular}

Figures 16 to 21 show the comparative consequence of sudden pull on the epoxy composites reinforced with untreated and $\mathrm{NaOH}$ treated King palm fibre which invariably reflects on the tensile properties of the epoxy composites vis-àvis increasing weight fraction of the untreated and treated King palm fibre reinforcement. There was a general improvement on the tensile properties of the epoxy composites reinforced with the $\mathrm{NaOH}$ treated King Palm fibre compared to the composites reinforced with the untreated King palm fibre.

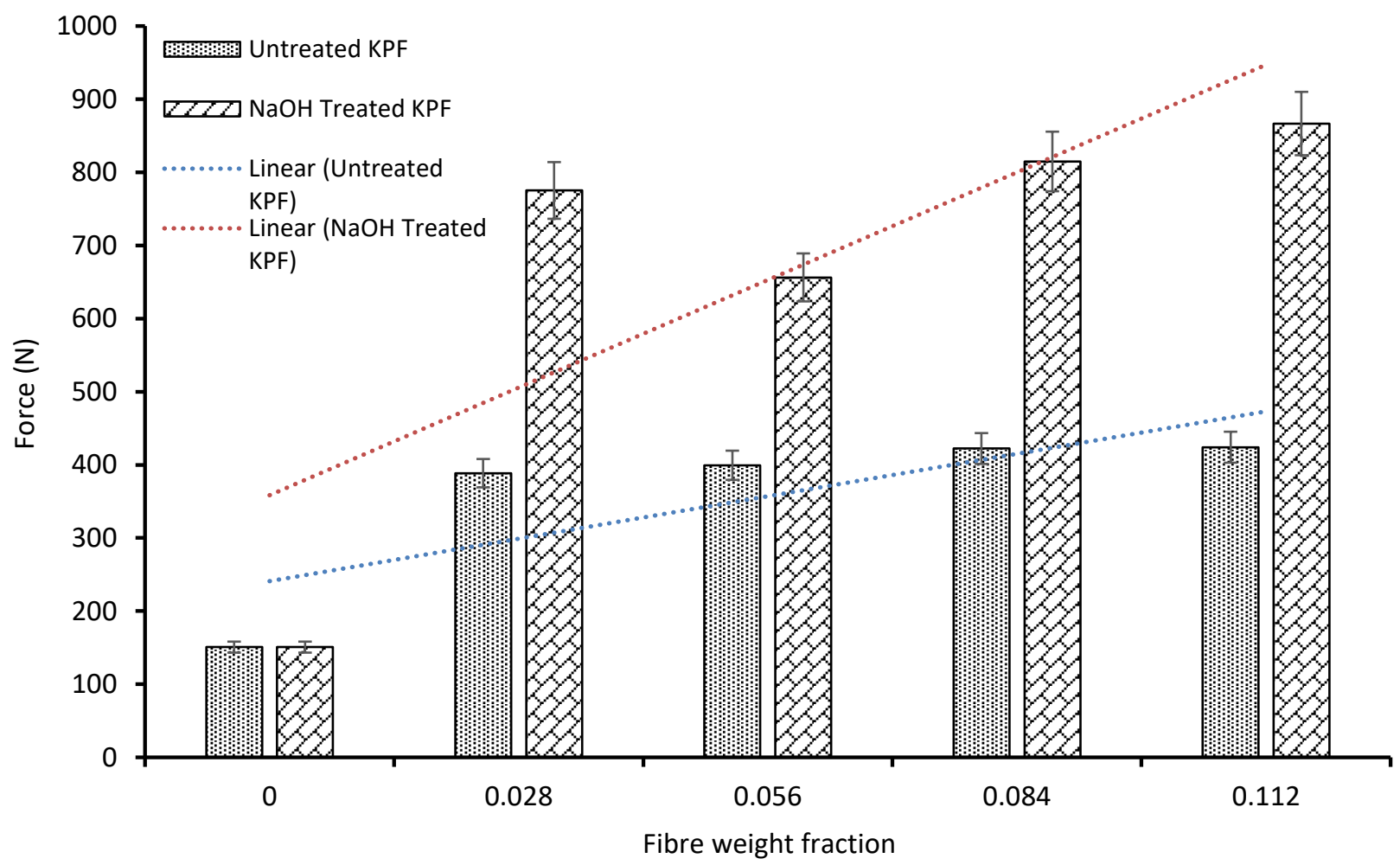

Figure 16:-Graph showing the comparative effect of the untreated and treated King palm fibre weight fraction on the mean force at break of the reinforced epoxy composite

Figure 16 displays that the mean force at break of the epoxy composites increased with the inclusion of untreated and $\mathrm{NaOH}$ treated King palm staple fibre weight fraction as indicated using the trend line in both cases. This is evidence of the reinforcement ability of the untreated and $\mathrm{NaOH}$ treated King palm fibre as it affects the performance of the epoxy composites under varying tensile loads. 


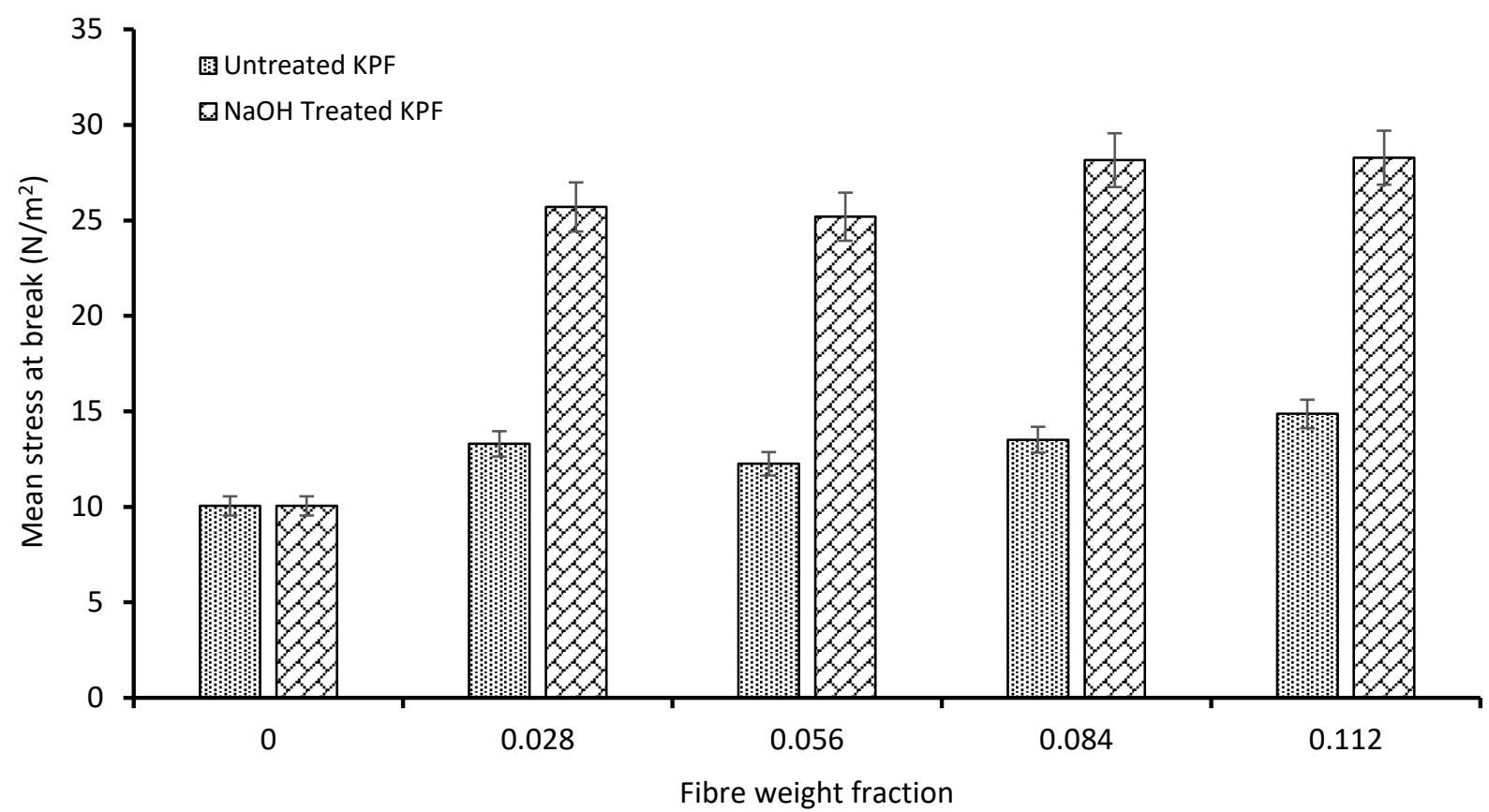

Figure 17:-Graph showing the comparative effect of the untreated and treated King palm fibre weight fraction on the mean stress at break of the reinforced epoxy composite

The mean stress at break defines the magnitude of stress at which the epoxy composites failed. The effect of the weight fraction of the untreated and treated King palm fibre on the mean stress at break of the epoxy composites is shown in Figure 17, where there was an increase in the mean stress at break on all samples. However, the bar chart in Figure 18 showing effect of weight fraction of the untreated and $\mathrm{NaOH}$ treated King palm fibre on the epoxy composites followed a reverse pattern with a reduction in the mean elongation at break as untreated and treated fibre weight fraction in the epoxy composites increased.

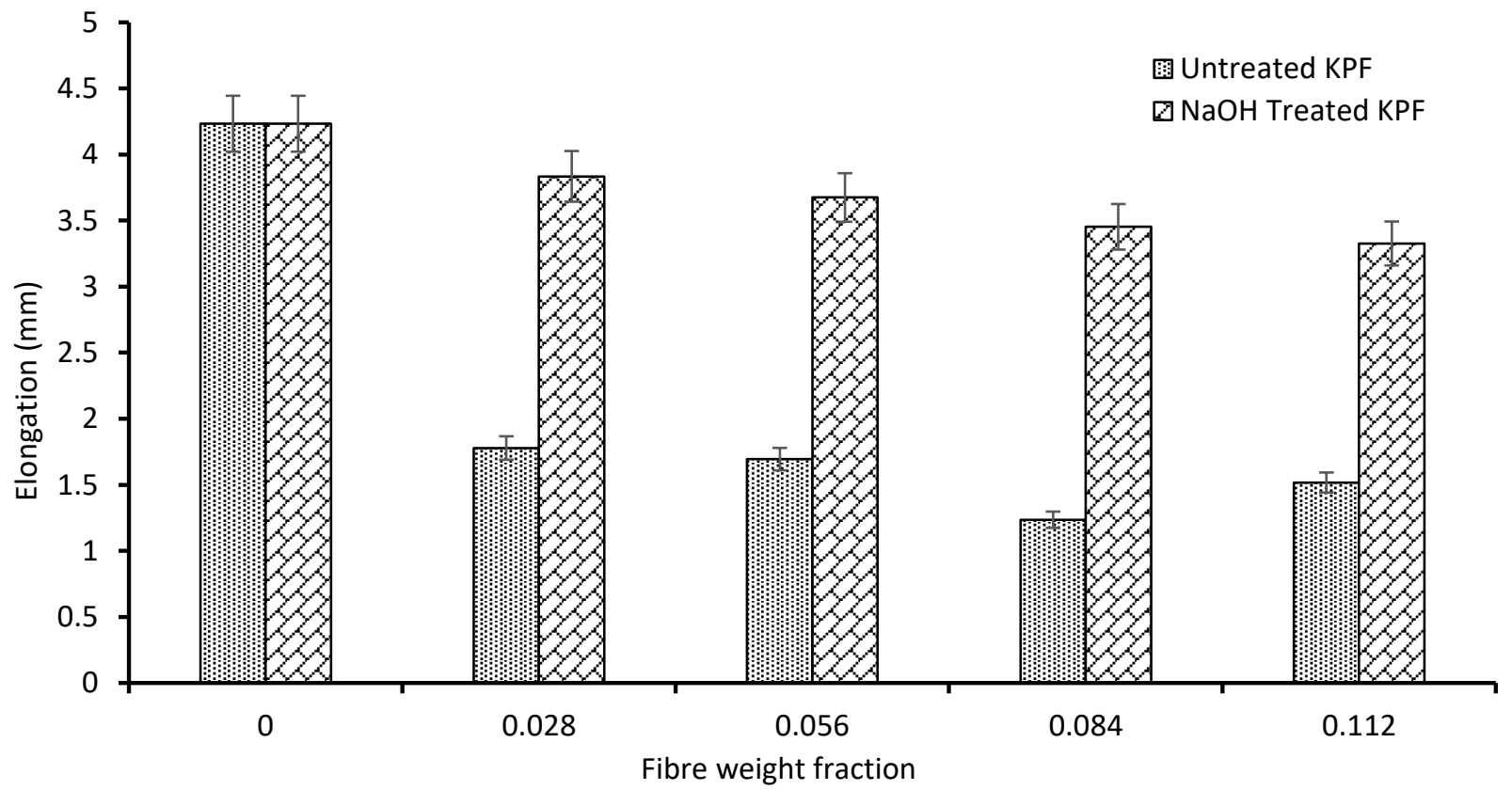

Figure 18:-Graph showing the comparative effect of the untreated and treated King palm fibre weight fraction on the mean elongation at break of the reinforced epoxy composite 
In Figure 18, the mean elongation at break is seen to be decreasing with increasing weight fraction of the untreated and $\mathrm{NaOH}$ treated King palm fibre. This trend differs from the unreinforced epoxy resin which exhibited the highest elongation at break amongst all the tested samples which means that the resistance to elongation may be attributed to increased crosslinking density due to the inclusion of the untreated and treated King palm fibre. The effect of varying weight fraction of the fibre in the epoxy resin on the mean ultimate stress at break of the reinforced epoxy composites is shown in Figure 19.

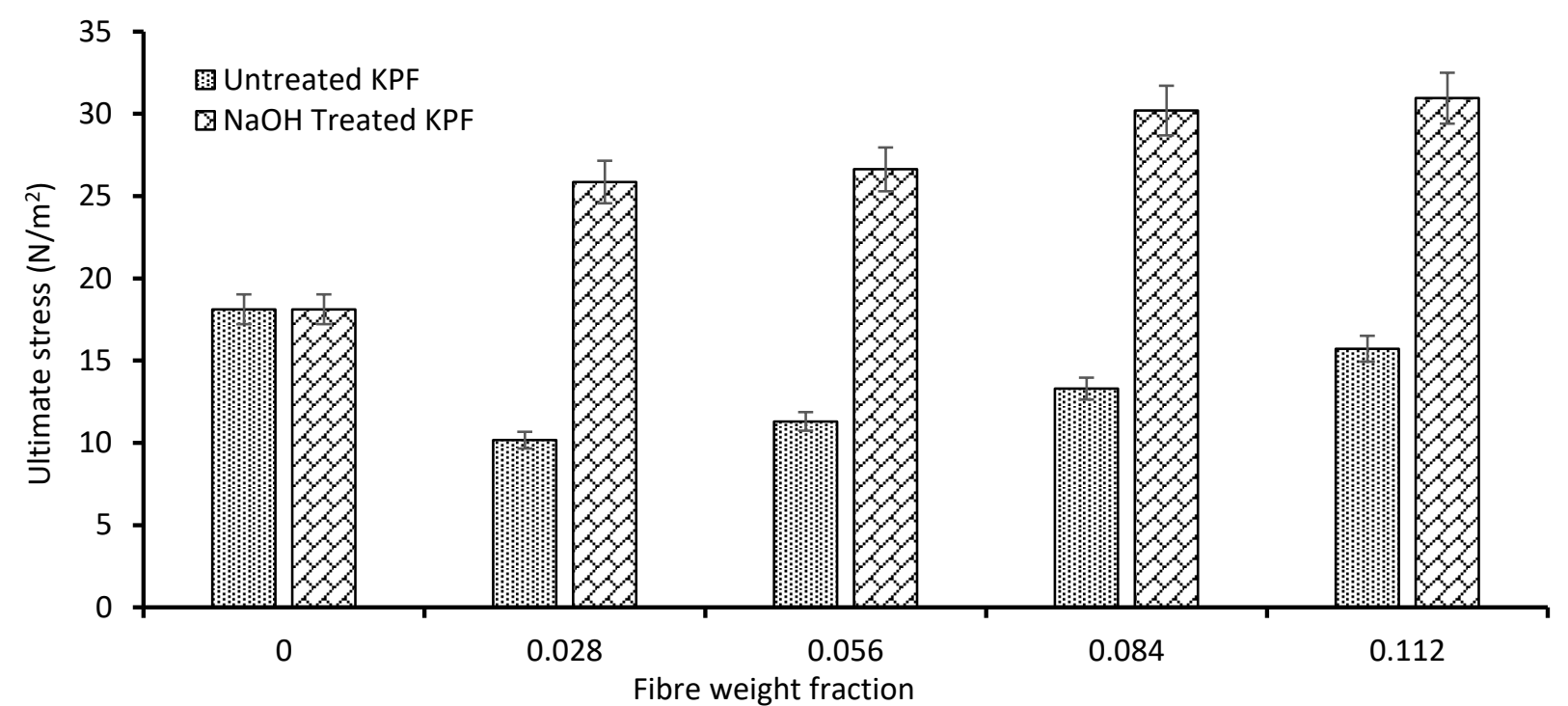

Figure 19:-Graph showing the comparative effect of the untreated and treated King palm fibre weight fraction on the mean ultimate stress at break of the reinforced epoxy composite

Figure 19 displays epoxy composites reinforced with the $\mathrm{NaOH}$ treated King palm fibre exhibiting higher mean ultimate stress in all cases. There was a gradual increase in the mean ultimate stress of the epoxy composites reinforced with the untreated King palm fibre but was lower than that of unreinforced epoxy. The reason for this may be attributed to the absence of shear stress between the fibres and the epoxy matrix in the case of the unreinforced epoxy which invariably may have led to a strengthened cured epoxy resin devoid of defects. The ultimate strength in the composites reinforced with the $\mathrm{NaOH}$ treated King Palm fibre may have increased due to the higher surface area of the fibres interacting with the surrounding epoxy matrix having little defects. This is in contrast to the epoxy reinforced with the untreated King palm fibre.

The effect of varying weight fraction of the fibre in the epoxy resin on the mean Young's modulus of the reinforced epoxy composites is shown in Figure 20. 


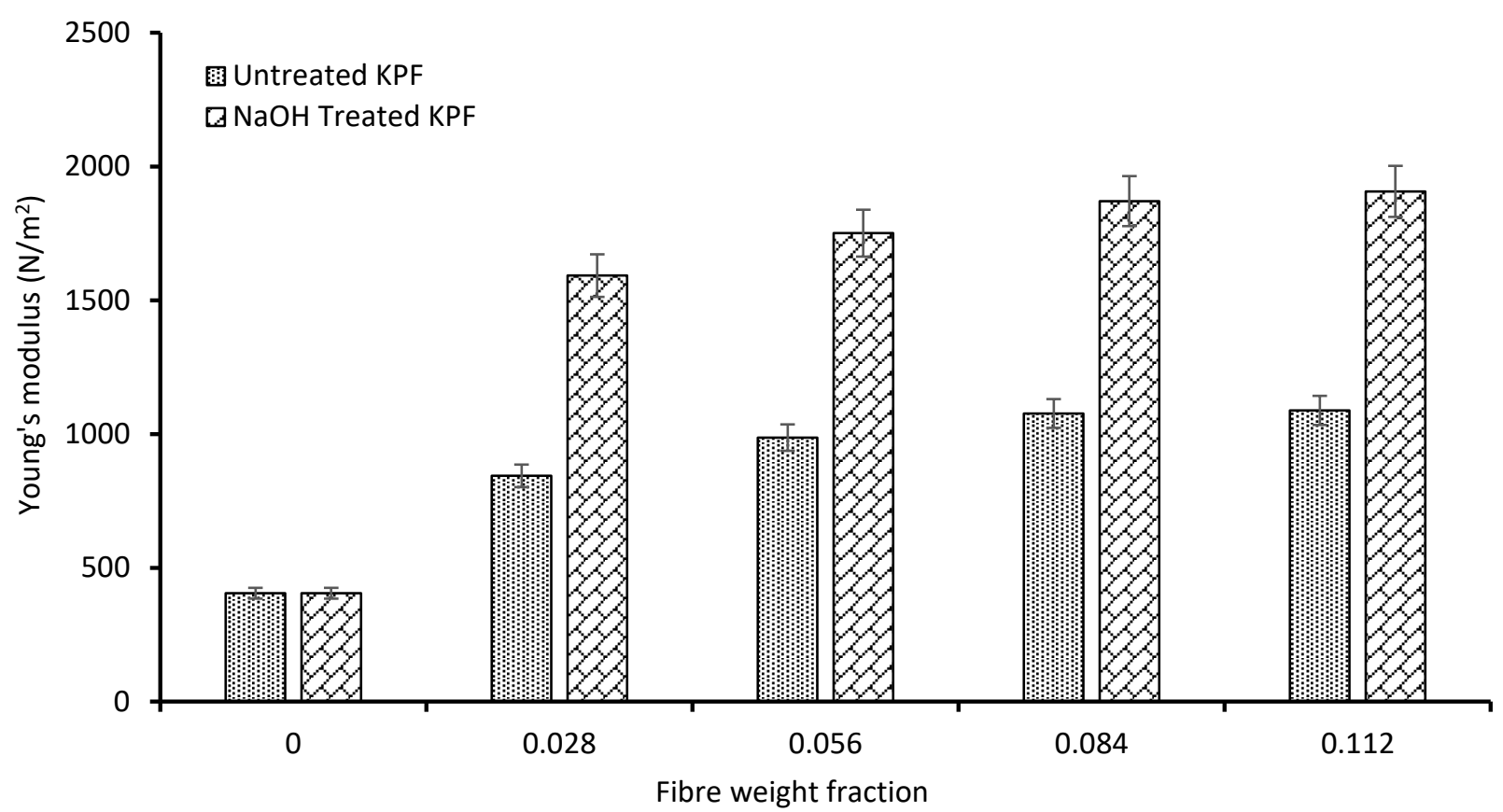

Figure 20:-Graph showing the comparative effect of the untreated and treated King palm fibre weight fraction on the mean Young's modulus of the reinforced epoxy composite

Figure 20 shows that there was a progressive marginal increase in Young's modulus due to an increase in the volume fraction of the untreated and $\mathrm{NaOH}$ treated King palm fibre in the epoxy composite up to 0.112 weight fraction. This means that the stiffness of the composites increased with increase in the King palm fibre reinforcement in the epoxy resin.

The effect of varying weight fraction of the fibre in the epoxy resin on the mean yield stress at break of the reinforced epoxy composites is shown in Figure 21.

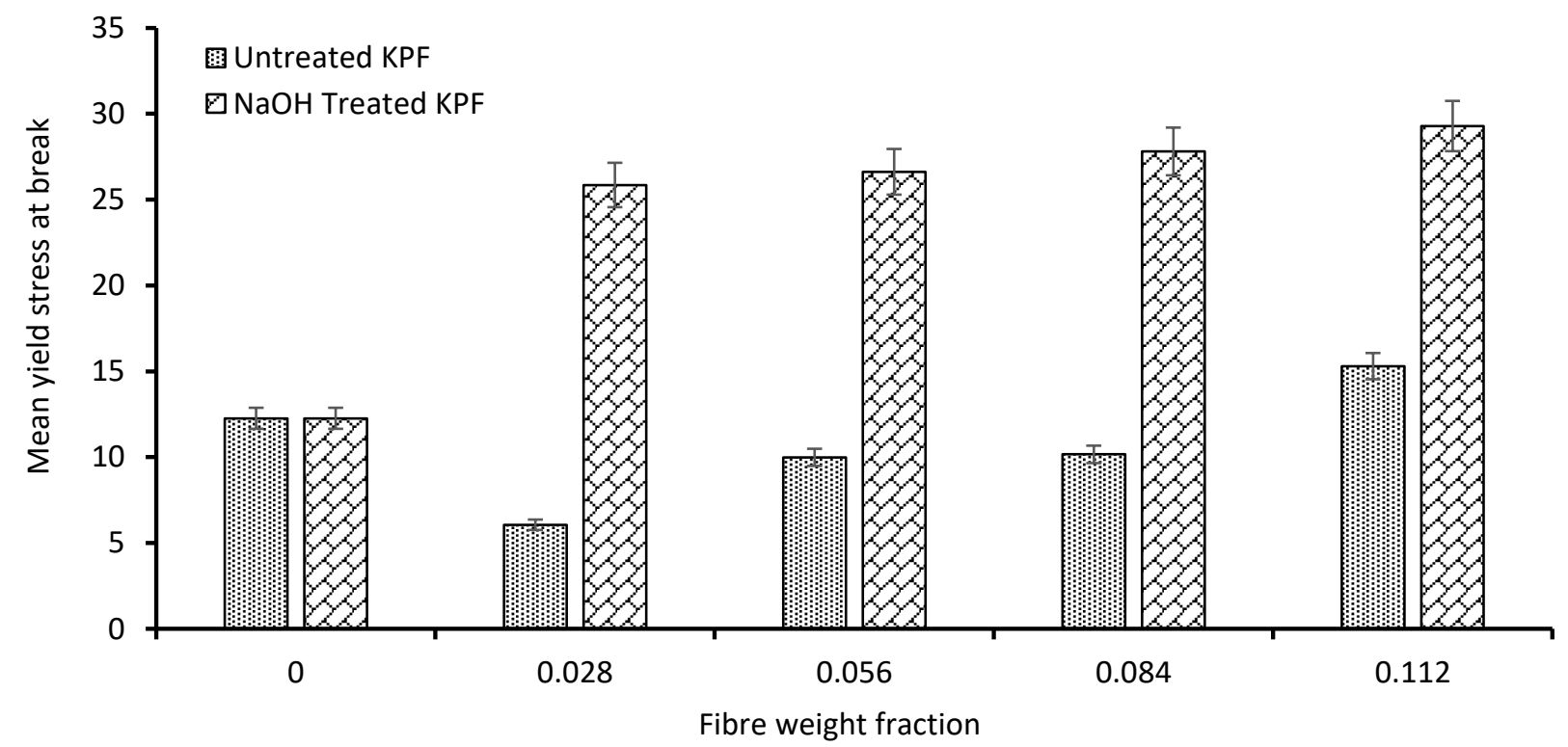

Figure 21:-Graph showing the comparative effect of the untreated and treated King palm fibre weight fraction on the mean yield stress at break of the reinforced epoxy composite 
From Figure 21, the mean yield stress increased with increase in fibre weight fraction. The mean yield stress decreased drastically with the inclusion of 0.028 weight fraction of untreated King palm fibre, but with increase in the percentage of untreated King palm fibre reinforcement up to 0.112 weight fraction, there was a gradual increase in the mean yield stress at break of the epoxy composites reinforced with the untreated King palm fibre.

\section{Conclusion:-}

Mercerized or $\mathrm{NaOH}$ treated and untreated pulverized King palm fibre has been used as reinforcement for epoxy resin. The initial reaction of all the epoxy composite materials was a pre-tensioning effect when subjected to a pulling shock which could either be as a result of machine error or fibre-epoxy interface defect in the composite samples. Increased weight fraction of the treated King palm fibre in epoxy resin increased the mean force at break from $150.75 \mathrm{~N}$ for the unreinforced epoxy resin to $424.07 \mathrm{~N}$ for the reinforced epoxy resin and mean Young's modulus from $404.82 \mathrm{Nm}^{-2}$ for the unreinforced epoxy to $1088.7 \mathrm{Nm}^{-2}$ and $1906 \mathrm{Nm}^{-2}$ for the treated and untreated King palm fibre reinforced epoxy composites. The results obtained for the mean ultimate stress, mean stress at break and mean yield point at break were also higher when the weight fraction of the reinforcement was increased from 0.028 to 0.112 in both cases of treated and untreated King palm fibre reinforced epoxy composites. However, the mean elongation at break, reduced from $4.233 \mathrm{~mm}$ for the unreinforced epoxy to $1.5173 \mathrm{~mm}$ and $3.3267 \mathrm{~mm}$ respectively for the treated and untreated King palm fibre reinforced epoxy composites. The tensile test results also confirm that the stiffness of the epoxy composites was amplified by higher weight fractions of the untreated and $\mathrm{NaOH}$ treated King palm fibre when used as reinforcement in epoxy resin compared to the unreinforced epoxy resin. Higher stiffness of the epoxy composites reinforced with the $\mathrm{NaOH}$ treated King palm fibre may be due to controlled, very low or no moisture content in the $\mathrm{NaOH}$ treated fibres before its use as reinforcement in the epoxy resin.

\section{Acknowledgement:-}

The assistance from Federal Institute of Industrial Research, Oshodi, (FIIRO), Lagos, Nigeria in testing and laboratory services is highly appreciated.

\section{Conflict of interest}

The authors hereby declare that there is no conflict of interest whatsoever associated with this work.

\section{References:-}

1. Ardhyananta, H., Ismail, H., \& Takeichi, T. (2007). Effect of organclay loading and ethylene glycol on mechanical, morphology and thermal Properties of ethylene vinyl acetate/organoclay nanocomposite. Reinforced Plastics and Composites, 789.

2. Aziz, S. H., \& Ansell, M. P. (2010). The effect of alkalization and fibre alignment on the mechanical and thermal properties of kenaf and hemp bast fibre composites: Part 1 - polyester resin matrix. Composites Science and Technology, 64(9), 1219-1230. Retrieved from http://opus.bath.ac.uk/2363/

3. Azwa, Z. N., \& Yousif, B. F. (2013). Characteristics of kenaf fibre/epoxy composites subjected to thermal degradation. Polymer Degradation and Stability, 98(12). https://doi.org/10.1016/j.polymdegradstab.2013.10.008

4. Dash, D., Samanta, S., Gautam, S. S., \& Murlidhar, M. (2013). Mechanical Characterizations of Natural Fiber Reinforced Composite Materials. Advanced Materials Manufacturing \& Characterization, 3, 1. https://doi.org/10.11127/ijammc

5. Di Landro, L., \& Janszen, G. (2014). Composites with hemp reinforcement and bio-based epoxy matrix. Composites Part B: Engineering, 67, 220-226. https://doi.org/10.1016/j.compositesb.2014.07.021

6. Doan, T.-T.-L., Brodowsky, H., \& Mäder, E. (2012). Jute fibre/epoxy composites: Surface properties and interfacial adhesion. Composites Science and Technology, 72(10), 1160-1166. https://doi.org/10.1016/j.compscitech.2012.03.025

7. Fiore, V., Di Bella, G., \& Valenza, A. (2015). The effect of alkaline treatment on mechanical properties of kenaf fibers and their epoxy composites. Composites Part B: Engineering, 68, 14-21. https://doi.org/10.1016/j.compositesb.2014.08.025

8. Fisher, G. (1994). Natural fibres: first choice for technical applications? Technical Textiles International, 3(1), 24-27. Retrieved from http://www.scopus.com/inward/record.url?eid=2-s2.00027963056\&partnerID=40\&md5=67ee1237a114972ec12fd7d8ae8a1f25

9. Hill, C. A. S., Khalil, H. P. S. A., \& Hale, M. D. (1998). A study of the potential of acetylation to improve the properties of plant fibres. Industrial Crops and Products, 8(1), 53-63. 
10. Hughes, M. (2012). Defects in natural fibres: Their origin, characteristics and implications for natural fibrereinforced composites. Journal of Materials Science.

11. Jiménez, A. M., Delgado-Aguilar, M., Tarrés, Q., Quintana, G., Fullana-i-Palmer, P., Mutjè, P., \& Espinach, F. X. (2017). Sugarcane bagasse reinforced composites: Studies on the young's modulus and macro and micromechanics. BioResources, 12(2), 3618-3629. https://doi.org/10.15376/biores.12.2.3618-3629

12. Joshi, S. V, Drzal, L. T., Mohanty, A. K., \& Arora, S. (2004). Are natural fibre composites environmentally superior to glass fiber reinforced composites? Composites: Part A, 35, 371-376. https://doi.org/10.1016/j.compositesa.2003.09.016

13. Jústiz-Smith, N. G., Virgo, G. J., \& Buchanan, V. E. (2008). Potential of Jamaican banana, coconut coir and bagasse fibres as composite materials. Materials Characterization, 59(9), 1273-1278.

14. Kongkaew, P. (2016). Mechanical properties of banana and coconut fibres reinforced epoxy polymer matrix composites. In Proceedings of Academics World 17th International Conference (pp. 66-71). Tokyo.

15. Lau, A. K. T., \& Ho, M. M. P. (2011). Recent research trend in natural-fibre composites. JEC Composites Magazine, 67(67), 3.

16. Mahjoub, R., Yatim, J. M., Mohd Sam, A. R., \& Raftari, M. (2014). Characteristics of continuous unidirectional kenaf fiber reinforced epoxy composites. Materials \& Design, 64, 640-649. https://doi.org/10.1016/j.matdes.2014.08.010

17. Murali Mohan Rao, K., Mohana Rao, K., \& Ratna Prasad, A. V. (2010). Fabrication and testing of natural fibre composites: Vakka, sisal, bamboo and banana. Materials \& Design. https://doi.org/10.1016/j.matdes.2009.06.023

18. Mutasher, S. A., Poh, A., Than, A. M., \& Law, J. (2011). The effect of alkali treatment mechanical properties of kenaf fibre epoxy composite. Key Engineering Materials, 471-472, 191-196. https://doi.org/10.4028/www.scientific.net/KEM.471-472.191

19. Obasi, H. . C., Iheaturu, N. C., Onuoha, F. N., Chike-Onyegbula, C. O., Akanbi, M. N., \& Ezeh, V. O. (2014). Influence of Alkali Treatment and Fibre Content on the Properties of Oil Palm Press Fibre Reinforced Epoxy Biocomposites. American Journal of Engineering Research (AJER), 03(02), 117-123.

20. Ramzy, A., Beermann, D., Steuernagel, L., Meiners, D., \& Ziegmann, G. (2014). Developing a new generation of sisal composite fibres for use in industrial applications. Composites Part B: Engineering, 66, 287-298. https://doi.org/10.1016/j.compositesb.2014.05.016

21. Rassmann, S., Paskaramoorthy, R., \& Reid, R. G. (2011). Effect of resin system on the mechanical properties and water absorption of kenaf fibre reinforced laminates. Materials \& Design, 32(3), 1399-1406. https://doi.org/10.1016/j.matdes.2010.09.006

22. Rong, M. Z., Zhang, M. Q., Liu, Y., Yang, G. C., \& Zeng, H. M. (2001). The effect of fibre treatment on the mechanical properties of unidirectional sisal-reinforced epoxy composites. Composites Science and Technology, 61(10), 1437-1447. https://doi.org/10.1016/S0266-3538(01)00046-X

23. Sapuan, S. M., Leenie, A., Harimi, M., \& Beng, Y. K. (2006). Mechanical properties of woven banana fibre reinforced epoxy composites. Materials \& Design, 27(8), 689-693. https://doi.org/10.1016/j.matdes.2004.12.016

24. Scarponi, C., \& Messano, M. (2014). Comparative evaluation between E-glass and hemp fibre composites application in rotorcraft interiors. Composites Part B: Engineering. https://doi.org/10.1016/j.compositesb.2014.09.010

25. Sreekala, M. S., \& Thomas, S. (2003). Effect of fibre surface modification on water-sorption characteristics of oil palm fibre. Composites Science and Technology. https://doi.org/10.1016/S0266-3538(02)00270-1

26. Tudu, P. (2009). Processing and characterization of natural fibre reinforced polymer composites. Mechanical Engineering.

27. Valadez-Gonzalez, A., Cervantes-Uc, J. M., Olayo, R., \& Herrera-Franco, P. J. (1999). Effect of fiber surface treatment on the fiber-matrix bond strength of natural fiber reinforced composites. Composites Part B: Engineering, 30(3), 309-320. https://doi.org/10.1016/S1359-8368(98)00054-7

28. Wang, W, Sain, M., \& Cooper, P. A. (2006). Study of moisture absorption in natural fibre plastics composites. Composite Science and Technology, 379-386.

29. Wang, Wei, \& Huang, G. (2009). Characterisation and utilization of natural coconut fibres composites. Materials and Design, 30(7), 2741-2744.

30. Xie, Y., Hill, C. A. S., Xiao, Z., Militz, H., \& Mai, C. (2010). Silane coupling agents used for natural fiber/polymer composites: A review. Composites Part A: Applied Science and Manufacturing, 41(7), 806-819. https://doi.org/10.1016/j.compositesa.2010.03.005

31. Yan, L., Chouw, N., \& Jayaraman, K. (2014). Flax fibre and its composites - A review. Composites Part B: Engineering, 56, 296-317. https://doi.org/10.1016/j.compositesb.2013.08.014 
32. Zhu, J., Zhu, H., Njuguna, J., \& Abhyankar, H. (2013). Recent development of flax fibres and their reinforced composites based on different polymeric matrices. Materials, 6(11), 5171-5198. 